\title{
Transformation of agriculture in Hungary in the period 1990-2020
}

\author{
József Lennert (iD) Jenő Zsolt Farkas (i) \\ Centre for Economic and Regional Studies, Institute for Regional Studies \\ 3 Rákóczi út, H-6000, Kecskemét, Hungary \\ lennert.jozsef@krtk.hu•farkas.jenozsolt@krtk.hu
}

\begin{abstract}
This paper aspires to provide a thorough overview of the transformation of the Hungarian agricultural sector from 1990 through to 2020. After a brief historical outline, three decades of changes and the present state are discussed in the context of the legislative framework, farm and ownership structure, production structure, land use and ecological sustainability. The changing role played by agriculture in the Hungarian economy and rural societies is also taken into consideration, while the overarching effects of EU accession and the introduction of the CAP are also investigated. The establishment of a legislative framework for privatisation and compensation in respect of the former collectivisation proved one of the major challenges during the transition to a market economy. As a result, this evened out the shares of all agricultural land in private and legal holdings in the first decade, with the number of smallholders exceeding one million. However, the following two decades were characterised by concentration, as the overall number of private holdings fell quickly, while there was an increase in numbers of those with more than 10 ha of utilised agricultural land. Hungary's political and economic transition was followed immediately by a dramatic decline in terms of production output. However, after the initial plunge, crop production started to rise again rapidly, so that by the early 2000s it had surpassed what had been achieved during the communist era. In contrast, the crisis in livestock production proved to be more prolonged.
\end{abstract}

Keywords: agriculture, Hungary, transition, crop production, livestock breeding.

\section{Introduction}

Three decades have passed since the fall of communism and Hungary's political and economic transition. We are now approaching a situation in which the time that has passed since that transition will be as long as the last period of communism in Hungary, the so-called Kádár-era. Surprisingly then, the current narrative remains a "post-communist" one that continues to look valid and indeed enjoys some popularity. In the first place, there are several ongoing social, economic and spatial issues that continue to be attributable to policies pursued under communism (with no complete erasure even three decades on, and following the major change of circumstances that accession to the EU denoted). And in the second place, the uneven development of the last few decades has given rise to a new range of inequalities and conflicts existing in parallel with the aforementioned inherited problems.

Agriculture is in some sense a robust system, but one that is obviously still highly dependent on natural conditions, and that manifests a greater-than-typical path de- 
pendency. This poses questions, concerning, inter alia: the extent to which 3 decades of post-communist development altered the development pathway that was followed previously; the characteristics that have remained, and the new features and trends that have emerged during the said three decades; Hungarian agriculture's ability to adapt to the changing circumstances; and the extent to which it is possible to regard it as one of the losers of the political and economic transition?

This chapter aims to discuss the development of Hungarian agriculture between 1990 and 2020, examining the transformation that occurred from multiple different aspects. The next section (Study area, materials and methods) gives a short introduction to the natural conditions for agricultural production that are present in the country, while also offering insight into the research materials and methods applied.

The third section (A brief historical outline of changes in Hungarian agriculture through to 1990) provides a brief overview of the development of Hungarian agriculture, highlighting some of the most important turning points, but emphasising development prior to the communist era.

The fourth section (Agriculture's changing legislative framework) discusses the legislative aspects of the scheme for agricultural privatisation and compensation, as well as the preparations for Hungary's accession to the EU. Also presented is the legislative framework underpinning emerging development trends where rural areas are concerned (integrated rural development and the protection and environmental-friendly use of the rural landscape).

The fifth section (Changes in the ownership and structure of agricultural holdings) discusses the transformation of the holding structure in Hungary by reference to legal status and size, with light also shed on the ongoing process of land concentration and consolidation.

The sixth section (Changes in the production structure of agriculture between 1990-2020) discusses the changes in the production structure characterising agriculture, with an analysis of the trends noted for different crops and breeds, and with spatial patterns also taken into account.

The seventh section (Land use and sustainable agriculture in Hungary) discusses land-cover change in Hungary during the examined period, while also offering insights into agri-environmental measures and farming's environmental footprint following the political and economic transition.

The eighth section (The role of the agriculture sector in the Hungarian economy) examines the present role of agriculture within the Hungarian economy, and also discusses two future challenges posing a threat in an otherwise generally favourable picture. i.e. the disadvantageous change characterising the agrarian price scissor, and looming climate change.

The ninth section (Rural societies in the shadow of agricultural transformation) describes the changing role of agriculture in the life of Hungary's rural population, with employment, income and symbolic aspects all discussed. The last section therefore serves as a conclusion, summarising the main findings and supplying best answers to the questions posed by the work. 


\section{Study area, materials and methods}

The study area

Hungary's natural endowments favour agricultural production. From the 1960s onwards, the country was basically self-sufficient overall, or at least in the agricultural and food products regarded as of key importance. Moreover, according to the National Chamber of Agriculture, Hungarian agriculture in its recent state has been in a position to supply up to 18-20 million people, if only appropriate technical developments are put in place (NAK 2018). Suitability for farming is further bolstered by the way $67 \%$ of the country is already under cultivation (Corine Land Cover 2018). The agricultural potential of Hungary's arable land can best be illustrated in line with the so-called golden crown value (Fig. 1) - a system for the classification of land in Hungary developed in the last decades of the 1800s and still used today. The value describes the net income given land with a given land use can yield, in this way revealing its original purpose relating to the levying of taxes. Several natural and economic factors are considered as the value is determined including edaphic and climatic conditions, topography, market accessibility and local costs of production (Bobvos 1996). On this basis, Hungary's best-endowed areas are seen to be located on the Great Plain, as well as the Little Hungarian Plain.

Where endowment is weaker (as marked in lighter shades of grey on Fig. 1) it is often also the case that an environmentally-sensitive lowland landscape is involved. In these circumstances, plantation farming is typical, due to the presence of sandy soils manifesting only a poor water balance. Areas of this kind include the Danube-Tisza Interfluve, Nyírség, and the Szatmári Plain, as all characterised by the presence of scattered farms.

\footnotetext{
1. Great Plain

2. Little Hungarian Plain

3. Transdanubian Hills and Mountains

4. North Hungarian Mountains

5. Transdanubian Mountains

6. Western frontier of Hungary
}

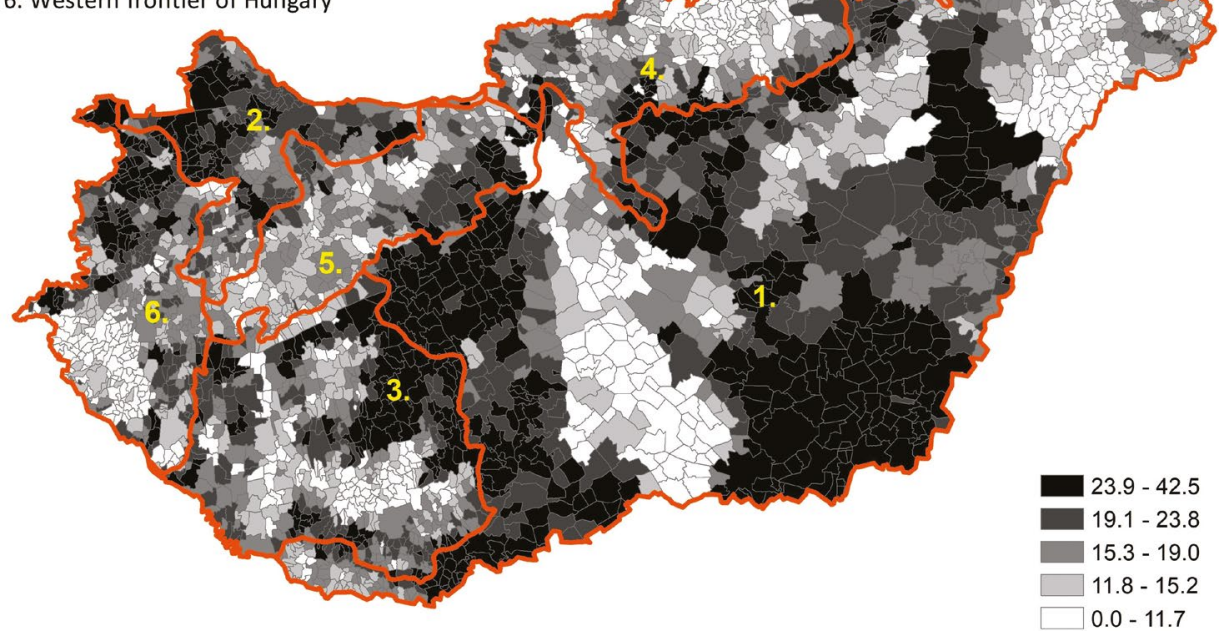

Fig. 1. The "golden crown value" of arable land in Hungary as of 2000, by settlements Source: authors' own elaboration based on the Agricultural Census 
The country's hilly (Transdanubian) and mountainous (Transdanubian and Northern Hungarian) landscapes also prove to be weaker when it comes to output from arable land, hence the existence here of vineyards and orchards, with forestry also playing major roles in agricultural production.

\section{Research materials}

Our research drew on secondary data sources, such as the agricultural statistical yearbooks published by the HCSO, the databases of the 2000 and 2011 Agricultural Censuses, and farm structure surveys. Some of these (e.g. the aforesaid Censuses hereinafter abbreviated to ÁMÖs) were accessed through the National Spatial Planning and Regional Development Information System (TEIR) - as operated by the Lechner Knowledge Center. In addition, we used the subject-related quantitative analyses prepared by the HCSO in both agriculture (e.g. involving regional comparisons) and related topics (e.g. involving sustainable development). A key source of statistical data was in turn the Eurostat Agri-environmental Indicators database, from which we mainly used data on changes in the degree of intensification of agriculture over time, as well as indicators of environmental impacts in the relevant sections. We found important additional data in the publications of the Research Institute of Agricultural Economics. This organisation mainly focuses on the financial and market processes of the primary sector, thus also analysing changes in the support system and its effects on land prices and rents. Other TEIR databases related to our topic also accessed included those on personal income tax provided by the National Customs and Tax Administration (as also including data on numbers of primary agricultural producers and incomes generated by smallholdings).

When it came to GIS databases, it was primarily data from Corine Land Cover and Natura 2000 sites that were used, as downloaded from the websites of the Copernicus Land Monitoring Service and the European Environment Agency. The borders of the administrative units of Hungary (e.g. counties and regions) derive from the ArcMagyarország database.

\section{Research methods}

In Hungary, the HCSO provides no settlement-level data on agricultural production other than that contained in Agricultural Censuses. As was noted above, the dates of the two available ones are 2000 and 2010, leaving no opportunity for analysis at this spatial level of processes affecting agriculture between 1990 and 2020. This situation necessitated a county-level presentation of long-term processes and trends, though data gaps ensured the need to step yet higher to the regional level (see Fig. 2).

Due to the descriptive nature of our work, we relied primarily on the processing of the relevant domestic and international literature, as well as on the qualitative analysis of secondary data. In addition to document analyses and statistical methods, we also used GIS to develop certain topics (e.g. the spatial dynamics of land-use changes). 


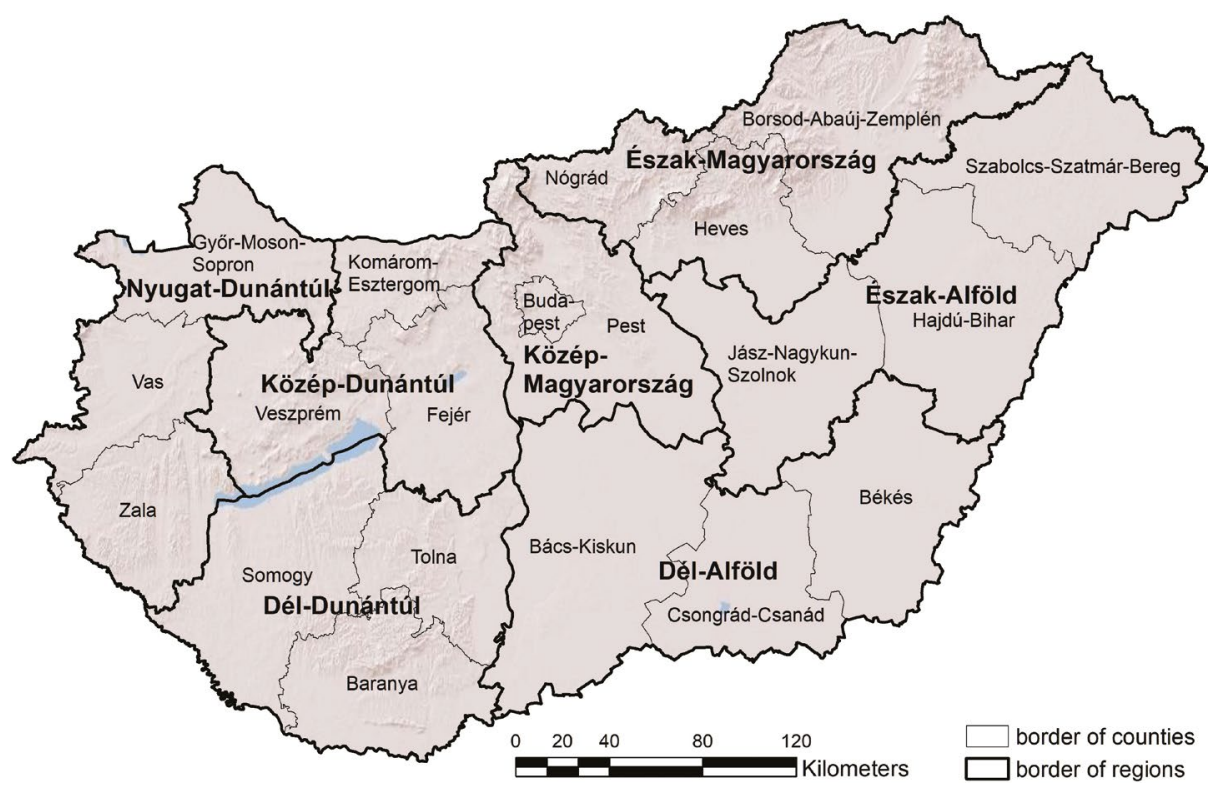

Fig. 2. Administrative boundaries of counties and regions Source: ArcMagyarország (2016).

\section{A brief historical outline of changes in Hungarian agriculture through to 1990}

Agricultural production has been present in Hungary for some 8000 years now, since the appearance of the Neolithic Körös Culture (Mester and Rácz 2010). However, the arrival of the semi-nomadic Hungarian tribes in the $9^{\text {th }}$ century marked a fresh start for agricultural development. In the Early and High Medieval Period, agriculture of a mostly subsistence nature was engaged in, within a dense network of small villages. The wide flood-prone territories of the Great Hungarian Plain gave rise to a special means of floodplain management and associated agriculture known as fokgazdálkodás. This entailed a mixture of regulation and adaptation to the natural conditions (Bellon 1996).

It was in the Late Medieval Period (as regeneration following the 1241-1242 Mongol invasion took place) that spatial specialisation in agriculture came to be enhanced. An emerging network of free royal cities and larger market towns provided a framework for local-market production, while - in the case of certain special product categories (especially wine and live cattle) - there was also an increase in the significance of longer-distance trading relationships (Laszlovszky 2006). However, a century-and-a-half of Ottoman Rule disrupted this promising development path, with the Kingdom experiencing major population loss, to the point where the settlement network across the Great Hungarian Plain was mostly destroyed. The only exceptions were the khas-towns subjected directly to the Sultan and therefore safeguarded against raids. Such raids, and indeed recurring wars combined with the sparse settlement network made extensive cattle breeding the most viable: in some years, close to 200,000 animals were herded to the western markets (Beluszky 2001). 
Once Ottoman rule had ended, (relatively) peaceful centuries spent within the Habsburg Empire allowed for an increase in the significance of wheat production. However, as distant lands could not be cultivated from the sparse settlement network, the unique scattered farm system of Hungary (known as tanya) emerged. To meet increasing demand, river regulation in the second half of the 19th century allowed for the expansion of arable land into much of the floodplain area (of the Tisza and its tributaries in particular). However, the consequences of this drastic transformation have to be seen as unfavourable in the long run.

The sandy areas of the Kiskunság and the Nyírség were not fit for wheat production. However, in the 19th century, the introduction of labour-intensive horticulture ensured that high yields were achievable even in these areas, with the result that areas underutilised previously were turned into productive orchards and gardening zones. Bulgarian immigrants also established lucrative gardening cooperatives in the surroundings of Budapest and along the Danube, with the aim being to meet the demand exerted by the rapidly increasing population of the capital city (Bódi and Savova 2018).

Rapid development and parallel societal changes led to a dual structure comprising a wide peasantry with small and barely viable holdings engaging in subsistence agriculture, and a very narrow landed elite accounting for a large share of the overall area utilised in agriculture and able to modernise their holdings, maintain competitiveness and profit from agricultural development (Kovách 2016). It was inequality of this kind that led to growing dissatisfaction as the 20th century progressed.

The "short" 20th century brought a series of transformations in Hungarian agriculture. The first of these was land redistribution taking place immediately after the Second World War ended. The communist takeover resulted in slavish following of the Soviet model, with a first wave of collectivisation starting in 1948 and lasting through to 1953. However, mainly thanks to resistance on the part of the peasantry, these efforts proved unsuccessful, with most collectives only lasting one or two years. Due to the hurried nature of the agricultural transformation, as well as the emphasis placed on heavy industry and infrastructure, agricultural production in the country only regained its 1938 level after 1957 (Molnár 1997). To provide supplies for the urban population and workers on large-scale construction projects, a strict scheme of food rationing and confiscation was enforced.

The uncertain political situation between 1953 and 1958 and the 1956 revolution ruled out any further efforts to collectivise agriculture for some years. However, the second attempt at collectivisation did reach a conclusion - in 1961 (Takács 2005). It had the effect of approximately 1,182,000 people joining collective farms. However, because this version followed the Soviet-type model with some compromises put in place, while also taking regional characteristics into account, it was more widely accepted. For example, the farmers of the fragmented landscape of the sand ridge on the Danube-Tisza Interfluve could also enter into so-called specialist Cooperatives or cooperative groups, in which collectivisation was not fully enforced (Krajkó and Mészáros 1984).

Overall, $85 \%$ of land was under large-scale cultivation on State Farms or agricultural Cooperatives, while the remaining $15 \%$ consisted of household plots cultivated by private farmers. It is important to note that, as early as 1966 (or 2 years before the introduction of what came to be known in the Eastern bloc as the 'new Hungarian Economic Mechanism'), the command-economy approach was eased somewhat in agriculture, with profit-oriented large-scale farming then encouraged (Takács 2005). Another significant di- 
vergence from the Soviet model lay in the fact that, from the mid-1960s on, Cooperatives received no planning quotas and could (within a set framework) decide how to organise their production (Udvardy 2010).

Developments in agriculture gathered significant momentum in the 1970s. Powered by state aid, growth lasted well into the early 1980s, and resulted in the evolution of agriculture on an industrial scale. Obsolete equipment was replaced, while vertical integration of food processing, the State Farms and the Cooperatives was accomplished (Enyedi 1988).

The long-term contracts between the COMECON countries guaranteed a stable and nearly-insatiable market for Hungarian agricultural products. Farm exports thus played a key role in the national economy, being instrumental in improving the balance of foreign trade. In this period, the country had the same indicators as the most advanced agrarian exporter countries, in terms of per-capita grain, pork, poultry and egg production, with $25 \%$ of agricultural and food-industry products exported on a regular basis (Juhász 2001). It was the first time in Hungary's history that the bulk of the country's agricultural exports were aimed at the Eastern European markets. As there was practically no limit to market absorption, allotment farming also flourished, and proved to be a major source of income supplementation for the rural population. As of 1981, household production accounted for $33 \%$ of the overall output from farming.

As a downside to this development, the industrial approach to agriculture failed to take local production circumstances into account, while high yields mainly reflected the excessive use of energy, fertilisers and pesticides. As a result, ecosystems were burdened with huge amounts of unnecessary pesticides, causing the same kind of "landscape erosion" as could be observed in Western Europe. The effect of farming on the large scale was a loss of landscape diversity.

Given the seasonality of labour demand in agricultural production, and in order to keep labour in the countryside, Cooperatives and State Farms established ancillary enterprises within the framework of the Cooperatives. These included sewing workshops, machinery industry, different industrial activities (in repair, assembly, construction and so on), or else were engaged in the supply of services. This therefore did much to diversify the rural economy, even if statistical recording did not view these as distinct from agriculture itself. An important role was for example played in housing and infrastructure-building in rural areas, with these accounting for more than 35\% of the overall value of production from Cooperatives through to the mid-1980s. Equally, activity of this kind was frequently in a position to cover up the actually loss-making nature of direct agricultural production.

By the mid-1980s, the inner reserves available for this kind of state socialism had depleted. Agriculture therefore entered into a period of stagnation (Udvardy 2010). Technology purchased from the Western world in the 1970s was already becoming outdated and decapitalised, even as capital for any kind of replacement was now lacking. At this point, the losses being sustained by Cooperatives were considerable, and the lack of capital was becoming a widespread hindrance. While energy prices were soaring, efficiency of production remained at the same level, with obvious and inevitable effects for the profitability of agriculture (Tamás 2001). The Hungarian Council of Cooperatives organised its first roadblocks in protest in 1988, with the intention of highlighting the perilous state in which agriculture now found itself. 


\section{Agriculture's changing legislative framework}

In the wake of the political changeover in 1989, the socio-economic environment and legislative framework surrounding agricultural production in Hungary changed fundamentally. With a re-established "Independent Smallholders Party" becoming a member of the first governing coalition (post-1990), the new political elite emphasised compensation for private property confiscated in earlier times and thus viewed the matter of agriculture through this lens. That said, it needs to be recalled that some $5 \%$ of Hungary's agricultural land never left the hands of its private farmers. Furthermore, workers and members of Cooperatives and State Farms were allowed to cultivate small plots (in total accounting for some $10-15 \%$ of the entire area utilised in agriculture). It was permitted for the produce generated in such circumstances to be used for personal consumption, or to be put on sale on the market (Csáki and Lerman 1997).

In 1991, The Hungarian Parliament passed a first Act relating to compensation (Law XXV of 1991). Sums were available for damage the state had inflicted unjustly on the property of citizens after June 8, 1948. In 1992, the Parliament passed two more laws (Law XXIV and Law XXXII) extending compensation for damage caused between 1 May 1939 and 8 June 1948, and for persons wrongfully deprived of their life or liberty for political reasons. Beneficiaries received compensation coupons under the above regulations, with these in essence amounting to bearer securities. Issuance of the coupons by the Compensation Office was commenced with in 1992. With them, it was possible to buy (1) property among that being sold in the course of privatisation, (2) the designated land of the old Cooperatives and State Farms or (3) designated municipal rental apartments and finally. A fourth alternative was for the coupons to be trade in for an annuity (Pongrácz 1997).

The further operation and transformation of Cooperatives was governed by the Law on Cooperatives (Law I of 1992), the Cooperative Transition Law (Law II of 1992) and the related Delivery of Land Act. The Law on Cooperatives was intended to provide a new legal framework for Cooperatives to work in a similar way to those present in Western-Europe (Csáki and Lerman 1997).

The main purpose of this legislation on compensation and the Cooperatives was to support the establishment of private farms and ensure a complete reframing of Hungary's agricultural sector. The land of the Cooperatives and State Farms was used to establish land funds for auction, or for members and workers of these establishments who had not had land previously. By way of the compensation auctions, 1.5 million new landowners received land; and by 1995 48.2\% of Hungary's arable land was already in the hands of smallholders (Csáki and Lerman 1997). At the end of the process (1996-1997), one-third of the arable land and forests designated for restitution had been purchased at auction by owners of the aforementioned compensation coupons (in the main, peasants whose land had been appropriated in earlier times). Another one-third remained under the ownership of members of agricultural Cooperatives, while the remaining one-third had been distributed among Cooperative workers who had lacked holdings of land before (Burger 2001).

With the creation of private farms supported, it was then necessary to develop a functional land market, hence Parliament's enactment of Law LV of 1994, which remained in force until 2013 (Law CXXII of 2013). Rules for the protection of arable land outside land trade were also codified. 
1994 saw Hungary submit its membership application with the EU, while Candidate status was granted in response by the European Council three years later. The start of the accession process made it unavoidable that the Hungarian state make significant efforts to develop agriculture. After 1990, domestic financial support was reduced significantly, leading to a nominally decreasing value of agricultural investment. In addition, successful preparation for accession demanded the reform of agricultural development and the introduction of new support schemes. Law No. CXIV of 1997 laid down first elements of the framework necessary for this. This legislation focused on increased competitiveness of agricultural output, and on equal opportunities between agro-businesses and other sectors, so that balanced capital gains and earnings for those living from the land could be assured. Concepts of a novel nature (for Hungary at least) were also introduced, e.g. the capacity of rural areas to sustain their local populations, the harmonisation of agricultural activities with environmental needs and local traditions, rural human-resource management, and the facilitation of agro-innovation.

Through to the accession, these guidelines defined the agricultural subsidy schemes of Hungary. Details on funded activities were published annually by the Ministry of Agriculture, but remained more or less consistent between 1998 and 2004, with up to 118 different payment titles in total. In fact, it was typical for the support regulations to adopt EU payment titles with a view to transition to the CAP system being facilitated. Issues therefore related to area payment schemes, support for young farmers, and so. Beyond that, there were some titles seeking to raise competitiveness in advance of Hungary's appearance within the Common Market (by way of subsidised purchases of machinery and technology), while others focused on capacity-building and boosts to production (investment, subsidies for the establishment of vineyards and orchards) - in advance of the prohibition of such measures with accession. The introduction of family farms in 2001 represented an important new element, with these receiving additional area payments and investment support. Payment titles of this kind accounted for more than a billion Euros a year (or several per cent of the central budget at that time) and were all financed by Hungary exclusively at that stage.

However, Hungarian funds were augmented by SAPARD - as farmers were in a position to receive financial support via this Special Accession Programme for Agriculture and Rural Development - one of several EU pre-accession funds. In reality, payments under the scheme were stalled for years, for multiple reasons arriving only just prior to the country's accession. The terms under which SAPARD funds could be applied for were less attractive to farmers than national schemes, and with few exceptions they did not even possess the necessary mobile capital for a successful application. Nonetheless, the SAPARD program was still beneficial to Hungarian agro-governance, providing a clear preview of the framework within which agriculture would have to be organised post-accession.

In the mid-1990's, having experienced the emergence of growing spatial disparities, political actors in Hungary recognised the need for a coordinated policy of development addressing the issues faced by rural areas. Law No. XXI of 1996 on regional development and regional planning would definitely need to be regarded as forward-looking (and in conformity with EU requirements) in comparison with regulations arrived at in neighbouring countries. However, while the law distinguished areas of agricultural-rural development (rural areas), its adoption was not followed by the taking of any more direct, concrete steps. In parallel with this law, the National Agrostructure and Rural Develop- 
ment Programme was prepared by the Ministry of Agricultural and Rural Development, gaining publication in 1997. While this Programme also took rural areas and their special needs into account, it did not come within the system of financial support (by virtue of the aforementioned Law No. CXIV of 1997). The government and agrarian professionals were more concerned with the upcoming fierce competition on the Common Market; and so gave priority to raising the level of competitiveness of farming. A consequence of this decision was the late acceptance of the Hungarian SAPARD plan alluded to above. As its first drafts were dominated by agricultural development, sources for the targeted development of rural areas were limited.

The institutionalisation of rural development started in 1998, when a department at the Ministry of Agricultural and Rural Development was tasked with addressing rural issues. In parallel with the national SAPARD plan, micro-regional plans were also prepared for 2000. Unfortunately, the problems referred to ensured that payments from the EU did not start to flow in until 2003.

Another important issue of rural development is the protection and environmental-friendly use of rural landscape. In the course the post-1990 compensation process, protected areas were managed in a dedicated land fund to avoid their privatisation. Unfortunately, this was not entirely possible given the lack of a confirmed and complete database of nature conservation areas that time. Later the National Parks attempted to purchase these unintentionally privatised areas with financial support from the state. The land in question included arable land, meadows and other agricultural areas too, so the National Parks also became asset managers and farm holders in conjunction with their regulatory role in land use. This privileged situation as regards the process became a source of conflicts, not only with farmers, but also with local authorities. Even Law No. LIII of 1996 on nature protection could not change that. While it contained recommendations that environment-friendly agriculture had to be subsidised, with farmers entitled to compensation in place of their lost profit by virtue of the nature protection regulations, it was not until 1999 that actions were taken in this regard. This ensured a further widening of the divide between natural protection and agriculture. On the basis of Government Decree 2253/1999, the National Agro-Environmental Programme attempted to ease the conflict from 2002. In 2003, the Programme's support scheme for the landscape and ecofarming already involved more than 5000 farmers, on some 230,000 ha of subsidised land (NAK 2016).

Meanwhile, in negotiations with the EU conflicts surrounding interests and ideas ensured a status for agriculture as a thorny issue. Hungary would have preferred to join the CAP without a transition period, but with quotas which would have allowed the country to rebuild production capacity in advance. On the other side, the European Union only intended to allow access to direct payments after a long transition period, and wanted quotas to be fixed by reference to a 1995-1999 base period. The differences remaining in Copenhagen could only be settled by way of a fudge. Hungary decided to apply the SAPS (Single Area Payment Scheme), only receiving subsidies at the level of 25\%, but in a position to top that up with an additional 30\% from the domestic budget (via complementarity involving a national direct payment). The share of EU support increased with each passing year, finally reaching 100\% in 2013. The reform of 2008 phased out the quota system (except in the case of sugar), in that way settling the other sticking point of the negotiations. 
Fulfilling the Copenhagen Criteria, Hungary acceded to the Union on 1st May 2004. After the shock of the political and economic transition, the circumstances in which agricultural activity might be engaged in changed once again. In this period, the Common Agricultural Policy and Common Market provided the new framework. Preferences regarding agricultural governance did not change, even after the accession, with the focus remaining on the development of agriculture directly. A study from the State Audit Office of Hungary (Állami Számvevőszék 2015) reveals that, while the 2007-2014 period saw around 10 bn Euros paid out as direct subsidies, the sources available under the New Hungary Rural Development Programme during the same period accounted for some 5.5 billion Euros only. Even from that sum, the first (improving the competitiveness of agriculture) and second (agro-environmental farming) axes accounted for $77 \%$, leaving only a little more than 1 bn Euros for the 3.9 million inhabitants of rural areas.

In many cases, the most recent wave of privatisation or (post-2012) long-term lease of the remaining arable land in the possession of the state may also have favoured the political and economic elite. An iconic example is the fate of Kishantos, which was operated for 21 years as a unique organic farm on 435 ha leased from the state. After 2013, notwithstanding the organisation's internationally acknowledged results, the contract was not renewed, and the area was transferred to new renters - some of whom had not engaged in agricultural activity before, and were non-resident (despite local status being a promoted goal of the lease mechanisms). They also returned to an intensive farming using pesticides, thereby bringing an end to what had gone before. József Ángyán, who served as a State Secretary at the Ministry of Rural Development between 2010 and 2012, resigned his post, openly challenging the latest government practice of land lease, and the presence of groups of agricultural oligarchs.

The compensation and Cooperative laws presented at the beginning of this section have had far-reaching effects on Hungarian agriculture, as related in part to forms of land ownership and in part to farm structure. The compensation process entailed the introduction of such specific forms of land ownership as shared and undivided common land ownership. The first is a specific proportion of ownership that cannot be identified as a specific piece of land (total 3.6 million hectares among 1.8 million landowners as of 2004), while the latter is a coercive community of ownership whereby members have no connection with each other (all such areas covering 1.8 million hectares as of 2011) (OH 2017). In 2012, the Hungarian Government declared that the abolition of undivided common land ownership was one of its political goals. According to the Ministry of Agriculture, these forms of land ownership are among the biggest obstacles to the development of Hungarian agriculture. This is partly because a true ownership approach can be difficult to achieve, with developments also running into various problems (e.g. in terms of financing) (Napi.hu).

In 2014, a pilot project began in Vas County to allow experience in running the process to be gained. This then helped with the shaping of Government Decree 374/2014, seeking to eliminate the undivided common land ownership created during the share land release to members and employees of Cooperatives and State Farms (OH 2017). In 2019, 2.4 million ha (1.06 million parcels) were under undivided common land ownership (Napi. hu). Finally, the Hungarian Parliament passed a law to abolish the undivided common land in July 2020. 
In its 2012 Rural Strategic Programme, the Hungarian government focused on the development of livestock breeding (with a strong emphasis on pig farming), and the modernisation of animal holdings. Other goals (the protection of rare breeds and a programme for the breeding of horses) are also connected to the main focus (Földmúvelésügyi Minisztérium 2012). Besides making use of subsidies, the government also introduced a 2015 and 2016 reduction in VAT from 27 to $5 \%$ in relation to certain animal products (beef, pork, lamb, milk and eggs), with a view to domestic demand receiving a boost.

The institutional structure of Hungarian agricultural and rural development went through certain changes following the EU accession. On account of the dissolution of the Ministry of Environment and Water, certain sectors (for example nature conservation) were reallocated to the Ministry of Agriculture in 2010. Between 2014 and 2018, rural development was transferred to the Prime Minister's Office; while the offices of the State Secretary were relocated to Kecskemét (a former agricultural market town). This was a special decentralisation measure withdrawn in 2018. In 2017, the tasks of the former paying agency (MVH) were taken over by the Hungarian State Treasury (MÁK) as its legal successor. At county level, the Government Offices continue to perform relevant tasks (OH 2019).

The payment of subsidies is in line with the EU's CAP regulations. In 2018, 170,000 applications were received by the Hungarian Treasury - in relation to 5 million ha of agricultural land (OH 2019). The planned overall level of agricultural subsidies was 2481 million Euros in 2018 , among which $54.9 \%$ was in the form of direct payments to farmers, while 27.9\% went on rural development and fisheries, 3.8\% on market and other subsidies and finally 13.4\% paid out as domestic support (OH 2019; Domán and Péter 2018).

\section{Changes in the ownership and structure of agricultural holdings}

As was discussed in previous sections, prior to the political and economic transition there were 130 State Farms and 1200 agricultural Cooperatives were responsible for two-thirds of agricultural output, while the rest was produced by small family farms (household plot farming), often existing as dependent on the Cooperatives (1.5-1.6 million holdings in total) (Kapronczai 2010). As can be seen, both the exhaustion of the former development pathway from the last decade of communism and the intentions of the newly-established democratic government pointed towards a radical change of structure where holdings were concerned.

As Fig. 3 indicates, the bulk of this rapid restructuring took place in the first decade of the examined period. After that, the role of legal entities as regards arable land decreased only slightly.

However, Table 1 shows clearly how reorganisation of the holding structure also continued into the new millennium: while the number of legal entities increased slightly, the number of private holdings plummeted. Other data from the ÁMÖ points out that, despite the slight reduction in the area of arable land cultivated, legal entities increased both their herds of livestock and employment (in annual working units) between 2010 and 2016, while the individual holdings continued to see declines in the values of these indicators. These findings point to ongoing concentration and specialisation in the agricultural sector. 


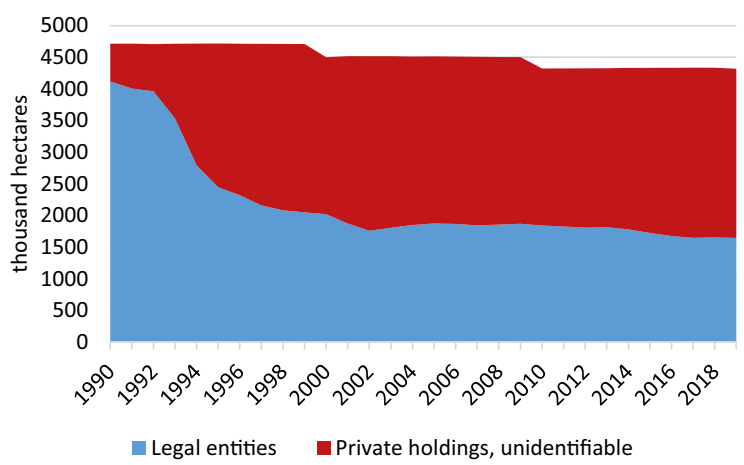

Fig. 3. The share of holdings in cultivated arable land by legal status, 1990-2020 Source: authors' own elaboration based on data from the Hungarian Central Statistical Office.

Table 1. Changes in numbers of holdings in terms of their legal status, 1991-2016

\begin{tabular}{|c|r|r|r|r|r|r|r|r|}
\hline \multicolumn{1}{|c|}{ Year } & \multicolumn{1}{c|}{$\mathbf{1 9 9 1}$} & \multicolumn{1}{c|}{$\mathbf{2 0 0 0}$} & $\mathbf{2 0 0 3}$ & \multicolumn{1}{c|}{$\mathbf{2 0 0 5}$} & $\mathbf{2 0 0 7}$ & $\mathbf{2 0 1 0}$ & \multicolumn{1}{c|}{$\mathbf{2 0 1 3}$} & $\mathbf{2 0 1 6}$ \\
\hline Legal entities & 2,600 & 8,382 & 7,813 & 7,927 & 7,405 & 7,970 & 8,090 & 9,388 \\
Private holdings & $1,395,800$ & 958,534 & 765,608 & 706,877 & 618,651 & 561,030 & 479,166 & 421,870 \\
\hline
\end{tabular}

Source: Agricultural Censuses of the Hungarian Central Statistical Office.

The legal entities are a diverse group, which includes reorganised or newly-founded Cooperatives (2018, p. 532), limited partnerships, joint stock companies and even National Parks. Amongst the private holdings, licensed traditional small-scale producers are of distinct legal status. As of the end of 2018, 261,000 smallholdings fell into this category (TEIR - HCSO).

As the data presented earlier indicate, private holdings are undergoing significant concentration. Data from Eurostat (also deriving from the ÁMÖ of the HCSO) reveal that the post-2005 reduction in numbers of private holdings has been confined to those with a utilised area of land under 10 ha (with the 667,000 existing in 2005 comparing with 375,000 in 2016). In the next category (over 10 ha utilised), there was actually an increase in the number of private holdings (from 40,000 in to 47,000 in 2016). In turn, where the category of farms with over 100 ha of land utilised was concerned, there was a near-doubling in the overall area in the years 2005-2016 (from 570,000 ha to 1,125,000) (Eurostat).

As the data in Fig. 4 demonstrate, farm-size differs markedly in line with legal status. The vast majority of private farms come under the smallest size category, but even then their share of the overall amount of agricultural land in use is modest. In contrast, while there are still only a few thousand farms in the largest size category (100 ha+), these cultivate almost half of the entire area of farmland in the ownership of private holdings. The picture is entirely difficult for legal entities, with farms in the largest size category also the most numerous group, and cultivating almost the whole area legal entities utilise (even as the role played by such farms in smaller size categories is near-negligible).

Data from the EU's SAPS (Single Area Payment Scheme) provides further details regarding the largest estates. Almost every holding over 1000 ha is a legal entity, with just $13 \%$ of these being persisting Cooperatives. There are only 575 holdings covering more than 1000 ha, but together these cultivate over 1,000,000 ha. The number of large pri- 


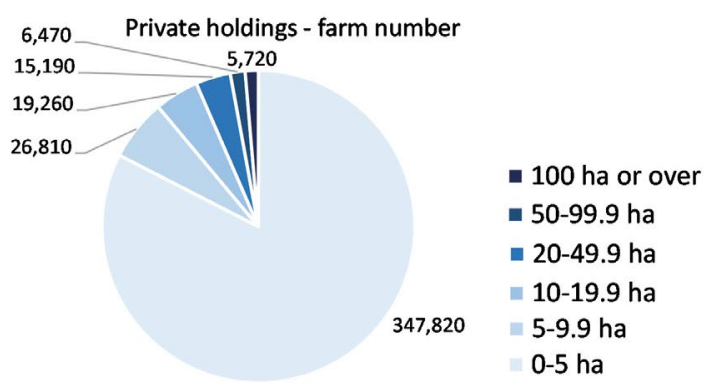

Private holdings - utilised agricultural area

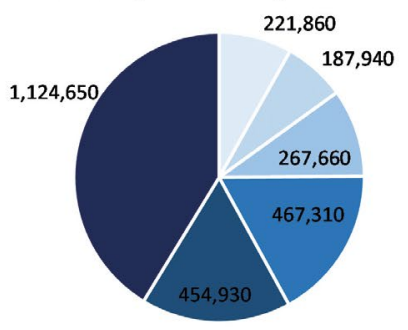

Legal entities - utilised agricultural area

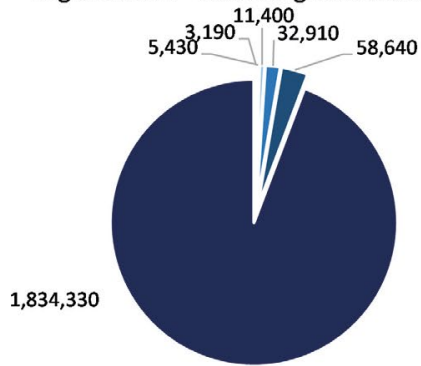

Fig. 4. Numbers of farms and areas of land utilised by them, in line with categories of size and legal status, 2016 Source: authors' own elaboration based on data from Eurostat.

vate holdings (of over 500 ha) is also increasing. According to Imre Kovách, around 20\% of these grew to this size via a series of smaller steps, at first by virtue of compensation, and later by renting or purchasing additional farmland. In contrast, $60 \%$ grew to sizes beyond 500 ha thanks to favourable political decisions. Some of these are long-term renters of national farmland or bought up land of the former State Farms at different auctions (sometimes at reduced price). This new group of private owners consists of the former elites of the State Farms and Cooperatives, as well as foreign investors, and - at least if some people are to be believed - political clients (Kovách 2016).

The appearance of large estates is very much differentiated regionally, with large holdings first emerging in the most developed western and central Transdanubian counties. Later, concentration also proceeded in high-fertility regions of the Hungarian Plain, where the conditions are suitable for the large-scale production of grain, maize and oilseeds.

The ongoing concentration is observable, by reference, not only to the agricultural area utilised, but also economic size. While numbers of farms with production worth less than 15,000 Euros decreased, numbers achieving a high value for production increased. However, livestock breeding facilities represent an exception, as - as we will see in the next section - the prolonged crisis in agriculture has had its impact, along with certain unfavourable practices when it comes to the restitution of land.

Another noteworthy characteristic of the Hungarian holding structure is that a majority of the arable land is rented out (Kovách 2018). Reasons for this are many, including the presence of undivided common land ownership, the non-viability of cultivation on smalIholdings, the impossibility of legal entities acquiring land in Hungary, and the stricter nature of land-purchase regulations following accession to the EU. 


\section{Changes in the production structure of agriculture between 1990 and 2020}

As Fig. 5 shows, the political and economic transition was immediately followed by a dramatic decline in both livestock breeding and crop production. The multiple causes of this phenomenon reflected the facts that:

- the agriculture sector peaked in the early 1980s (see third subsection), with a decline reflecting outdated technology and the withdrawal of capital already therefore in progress,

- the reorganisation of the holding structure, ongoing agricultural compensation (see fourth subsection), and the poor state of the Hungarian economy all hindered investment,

- market loss resulted from the disintegration of COMECON,

- shifts in inland consumption patterns took place, partly as a reaction to economic hardship.

For 1993, the recorded output from crop production fell below that in 1960. However, after the initial plunge, crop production and livestock breeding followed different courses. Output from crop production started to rise again rapidly (if with setbacks in years of unfavourable weather conditions like 2000), and by the early 2000's it surpassed the output of the communist era. In contrast, the crisis in livestock breeding was more prolonged, only reaching its low-point in the early 2010's, at little more than half the initial value, and thus comparable with livestock breeding output from the early 1960's. In the last decade, both sectors reported growth, with the result that total agricultural output almost reached values from the 1990s.

However, as detailed analysis will show, these main figures summarise a diverse picture made up of opposing trends: while the production of certain crops skyrocketed, others lost their former significance. Furthermore, the risky process of animal husbandry was not implemented evenly. Any pointing-out of these differences serves in helping us understand the various driving forces behind overall change in domestic agricultural production.

Ever since the Ottoman era, cereal production has played a central role in Hungarian agriculture: as of 1990, cereals covered around $43 \%$ of the total agricultural area. This

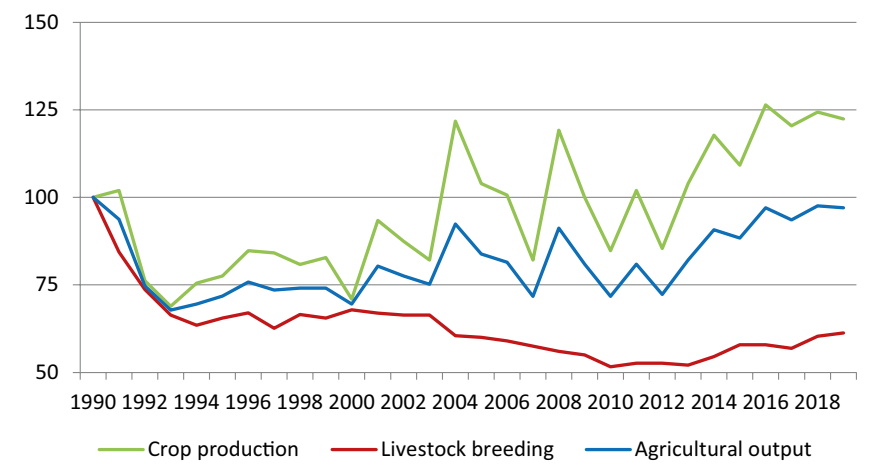

Fig. 5. Changes in total output from agricultural production, crop production and livestock breeding, 1990-2020 (1990=100\%)

Source: authors' own elaboration based on data from Hungary's Central Statistical Office. 
pivotal feature of Hungarian agriculture remained unchanged (with the share of cereal cover slightly increasing to $45 \%$ ). However, this was mainly due to the overall loss of agricultural land (see subsection), since the cereal-producing area also reduced (from 2.8 to 2.4 million ha).

In the cases of both cultivated area and volume of production, wheat and maize were the most important crops by a wide margin in 1990 as well as 2019 (Fig. 6). Alongside these two, only barley contributes significantly to cereal production. The cultivation of rye, oat, triticale and rice is limited to only small areas, and is almost negligible in comparison with the top three grain species.

The cultivation of wheat is of considerable importance in every part of the country (Fig. 7). The relevant spatial patterns remained largely unchanged during the three deca-

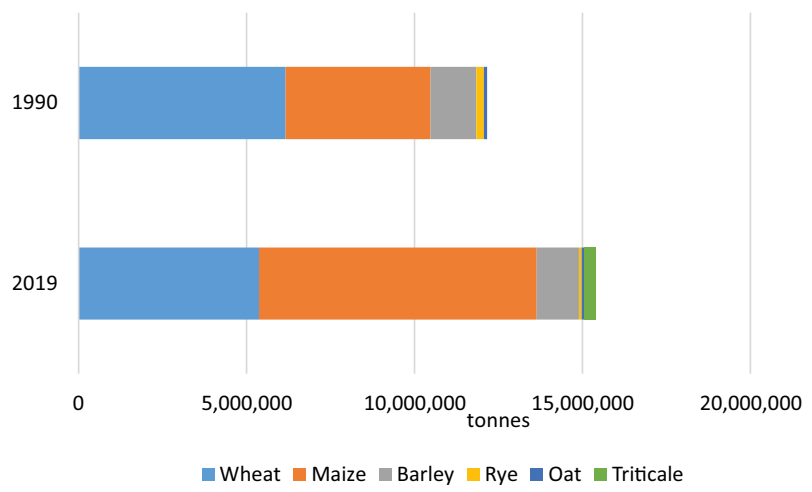

Fig. 6. Cereal production by main species as of 1990 (1987, in the case of oats) and 2019 Source: authors' own elaboration based on data from the Hungarian Central Statistical Office (2019), Spatial Statistical Yearbook of Hungary (1990), and Agricultural Yearbook of Hungary (1987).
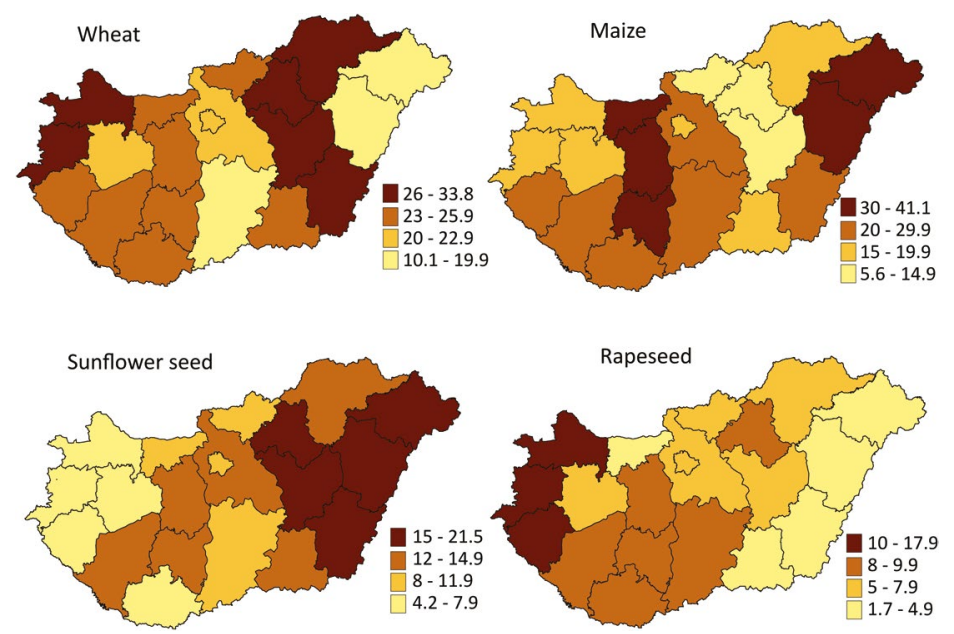

Fig. 7. Percentage shares of arable land in Hungarian counties accounted for by wheat, maize, sunflower seeds and rapeseed as of 2019

Source: authors' own elaboration based on data from the Hungarian Central Statistical Office. 
des under study, only showing a noticeably lower share in counties characterised by poor-quality sandy soils (e.g. Szabolcs-Szatmár-Bereg and Bács-Kiskun). However, the share is especially high in counties with extensive chernozem areas (Békés and Jász-Nagykun-Szolnok). The cultivation pattern for maize offers a somewhat complementary picture, with an especially high share in counties not dominated by wheat (e.g. Szabolcs Szatmár-Bereg); and its cultivation is limited to cooler mountainous areas (e.g. Nógrád and Heves). Wheat is mainly produced for human consumption, while maize is mostly used as fodder.

The production of other cereals is distributed in a more spatially-differentiated way. Since barley favours a more balanced precipitation, its cultivation was more significant in Western Transdanubia. This pattern is still visible. Additionally, the most popular Hungarian beer brand situated in the region (Soproni/Heineken Hungaria Zrt.) made a central element of its image that its flagship beer is made from 100\% Hungarian barley. In 1990, rye still reached a significant share in counties with sandy soils unfavourable for wheat production (6\% of arable land in Bács-Kiskun and almost 10\% in Szabolcs-Szatmár-Bereg). However, by 2019, it had mostly been replaced by triticale - whose environmental requirements are similar.

In the last three decades, the average yields from cereal production have increased (Fig. 8). The average yield of maize nearly doubled, while in the cases of wheat and barley, growth was only moderate. However, there is still much room for development: while in Western Europe, average yields can reach three-quarters of those potentially achievable with wheat types, in Hungary yields only reach a level half as high as the optimal results (Varga et al. 2013).

Besides cereals and vegetables, the most important crops cultivated on arable land are oilseeds (rapeseed, sunflower seed), fodder crops (maize silage, legumes, soybeans), sugar beet and potatoes. As Figs. 9-10 show, while the total for land used remained roughly the same, a drastic shift among the main crops took place. The increasing demand imposed by both the food industry and biodiesel production (OECD - FAO 2019) led to a rapid increase in oilseed cultivation. The increase in the area under rape was particularly spectacular. The changes are not only quantitative: different hybrid rapeseeds are quickly

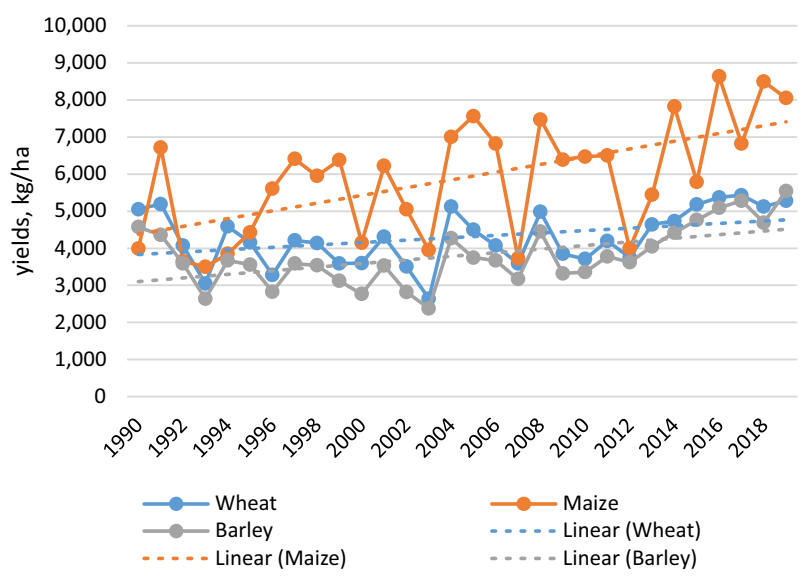

Fig. 8. Yields of wheat, maize and barley, 1990-2019

Source: authors' own elaboration based on data from the Hungarian Central Statistical Office. 


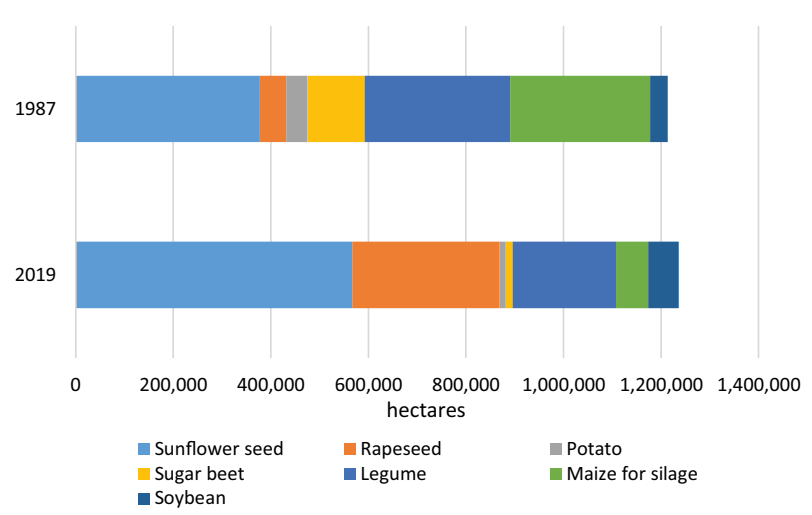

Fig. 9. The cultivated areas of certain key crops on arable land (other than cereals), 1987, 2019 Source: authors' own elaboration based on data from the Hungarian Central Statistical Office (2019), Agricultural Yearbook of Hungary (1987).

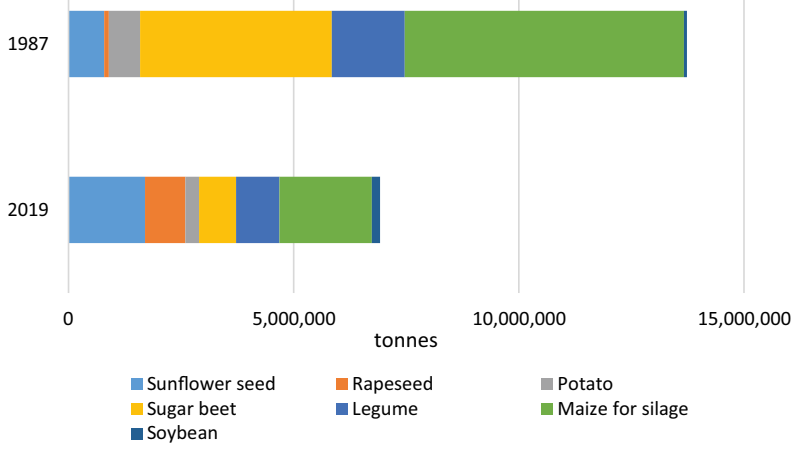

Fig. 10. Produced quantities of certain key crops on arable land (other than cereals), 1987, 2019

Source: authors' own elaboration based on data from the Hungarian Central Statistical Office (2019), Agricultural Yearbook of Hungary (1987).

gaining ground over other varieties (Popp et al. 2018). As Fig. 7 shows, the cultivated areas of sunflower seed and rapeseed complement each other: while sunflower reaches its highest shares on the Great Hungarian Plain, rapeseed is preferred in Western Transdanubia, where the climate is more moderate, and precipitation greater (see subsection).

On the other hand, the cultivation and production of fodder crops declined markedly. And, as we will see, this is connected to the prolonged crisis in livestock breeding and disintegration of the vertical agricultural production system existing previously. Soybean, as the most important protein supplement in livestock breeding, represents an interesting exception to this trend. However, even after the significant increase, the amount of the crop grown cannot cover the internal demand - which is in fact a common feature across the EU (FEFAC 2019).

The production of sugar beet and potato is also down. As can be seen in the fourth section, the strict quotas on sugar production introduced by the EU led to the near-complete elimination of Hungarian sugar production. From among the 12 sugar plants present 
before only the one at Kaposvár is operational today. This also led to a decrease in sugar-beet production (from 4-5 to 0.8-1 million tonnes/year). Because of the increasing yields, the reduction was larger than this in the case of the area cultivated. There are more complex reasons behind the reduced growing of potatoes, like changes of demand domestically and shrinkage in the area of suitable farmland - the latter perhaps as an early warning sign arising out of ongoing climatic change (Rubi Raymondo et al. 2018).

Other crops worth mentioning include flax and hemp produced for fibre, as well as tobacco and poppy seeds. All of these were cultivated on only a few thousand hectares even prior to the transition, and are absolutely negligible now. They nevertheless represented a significant source of income for certain local communities (e.g. tobacco in Szabolcs-Szatmár-Bereg county).

The climatic conditions in Hungary are ideally suited to the production of a wide variety of fruit and vegetables, and, as the third section pointed out, there is a long tradition of horticulture here, it also being a key part of the Hungarian agricultural sector under communism. Over the last three decades, the volume of output from the horticultural subsector has reduced by one third. Vegetable production dropped from around a million tonnes a year to 700,000 , while production of fruit shrank from about 1.2 to 0.8 million tonnes a year (Fig. 11).

The reasons for the shrinkage include (after Erdész et al. 2019):

- the crisis, and reduced consumption in COMECON markets,

- increasing competition from producers inside and outside the EU,

- the restructuring of the food processing industry (especially canning) post-transition,

- changes in consumption patterns domestically,

- limited cooperation between producers leading to higher costs, and a weak assertion of interests during price negotiations,

- (as a consequence) a large gap between prices at the producer and retail stages (for example 2- to 5-fold where apples were concerned, depending on weather conditions during the growing season),

- the disparate nature and uneven quality of production (disfavouring entry on to a market dominated by supermarket chains),

- years featuring unfavourable weather conditions (late spring frosts, droughts, etc.).

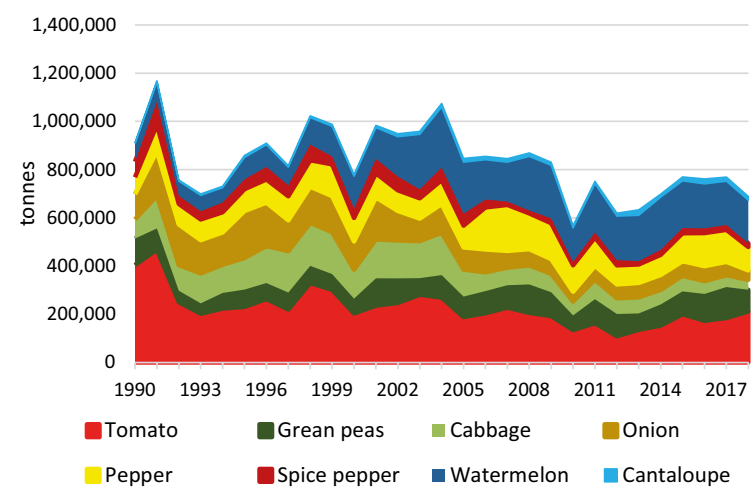

Fig. 11. Changes in vegetable production, 1990-2018

Source: authors' own elaboration based on data from the Hungarian Central Statistical Office. 
Amongst the vegetables produced, tomatoes achieve the greatest significance as regards volume (Fig. 11), while green peas are planted over the largest area (assuming maize is excluded). The lion's share of the produced tomatoes serves as raw material for the canning sector. During the examined period, the production of onions, and traditional Hungarian paprika dwindled due to increased competition (mostly outside the EU), as well as origin and quality concerns, while the production of watermelons reached new heights.

Fig. 12 highlights how the production of vegetables is most significant in the Great Hungarian Plain area, with the highest concentration on the Southern Hungarian Plain. Some crops have a more concentrated area of production (e.g. watermelons in Békés and Szabolcs-Szatmár-Bereg), while others show a more diffuse pattern (e.g. tomatoes). Some crops (like paprika and other spices) are still produced predominantly in their traditional area, while in other cases (as with onions), a shift of heartlands is observable. Some counties suffered a significant reduction in vegetable production after the transition (with Szabolcs-Szatmár-Bereg County for example being among the top producers of carrots in 1987). Since the agglomeration of Budapest is Hungary's largest market, the major role of Pest County is understandable. However, even from Bács-Kiskun and Csongrád-Csanád Counties, a large share of the production goes directly to the fresh markets of the capital city.

Apple production dominates the Hungarian fruit sector by a large margin (if the growing of grapes for wine is excluded) (Fig. 13). In the past, much of the apples produced were exported to the Soviet Union, hence difficulties for producers seeking to cope with the crisis on eastern markets. The problems in question (a reluctance to change to more popular varieties, lack of cooperation, low profitability especially for industrial apples, uneven/unfit quality) led many producers to give up their orchards. Other cultivated fruits taking a share worth referring to include sour and sweet cherries, plums, pears, apricots, peaches, walnuts and different berries (e.g. strawberries, raspberries, redcurrants and elderberries). The disappearance of raspberry production is especially intriguing. While Hungary was among the top raspberry producers in Europe in the 1980s, recent production has only been at a few per cent of the peak values, leaving newly-emerged growers in Serbia and Poland to dominate European markets. These countries have relied on lar-

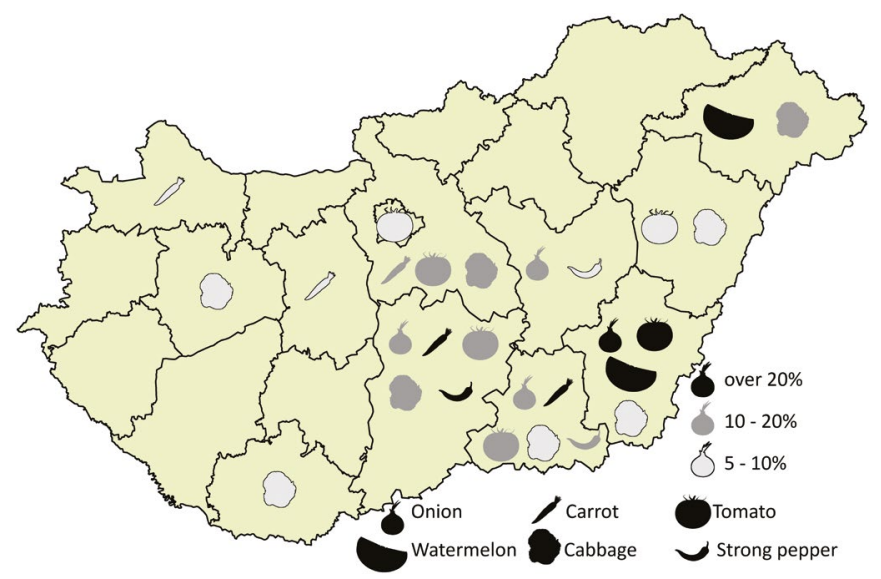

Fig. 12. Shares of the main vegetables accounted for by counties in 2018

Source: authors' own elaboration based on data from the Hungarian Central Statistical Office. 


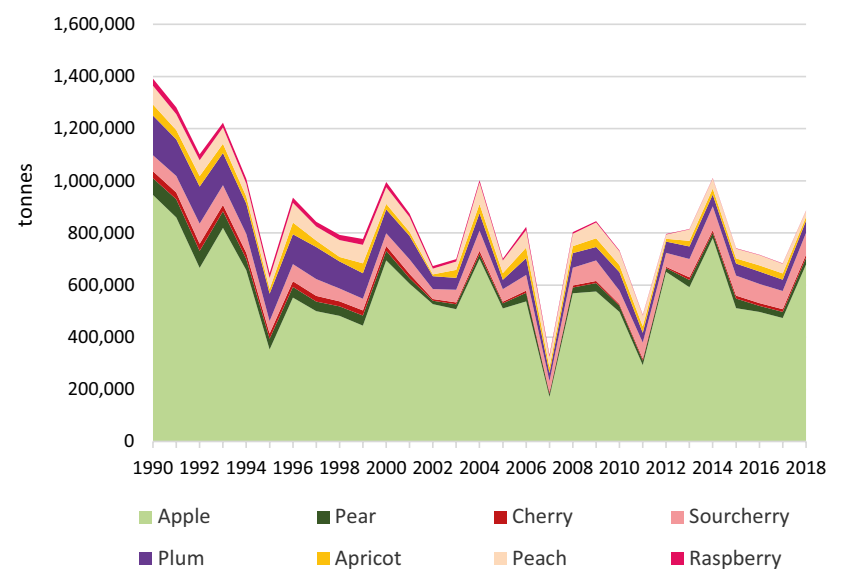

Fig. 13. Changes in the production of key fruit crops, 1990-2018

Source: authors' own elaboration based on data from the Hungarian Central Statistical Office.

ge-scale production, while the aging owners of the smaller Hungarian raspberry farms had to face both labour shortages and lower profitability. Recent trends for climate would also seem to favour the competition over Hungary (Isépy et al. 2018).

Fig. 14 confirms the high level of concentration of Hungarian fruit production, with Szabolcs-Szatmár-Bereg County in the lead nationally (accounting for more than half of total apple production), followed by Bács-Kiskun, Borsod-Abaúj-Zemplén and Pest Counties, which could all be seen as having noteworthy shares of the total. The distribution of certain fruits (e.g. peaches and apricots) is driven by both climatic conditions and historical traditions.

The primary aim of grape production in Hungary is winemaking. Following the economic transition, annual output fell in terms of amounts of both grapes and wine. As in the case of other fruits, producers felt the loss of protected COMECON markets, and incre-

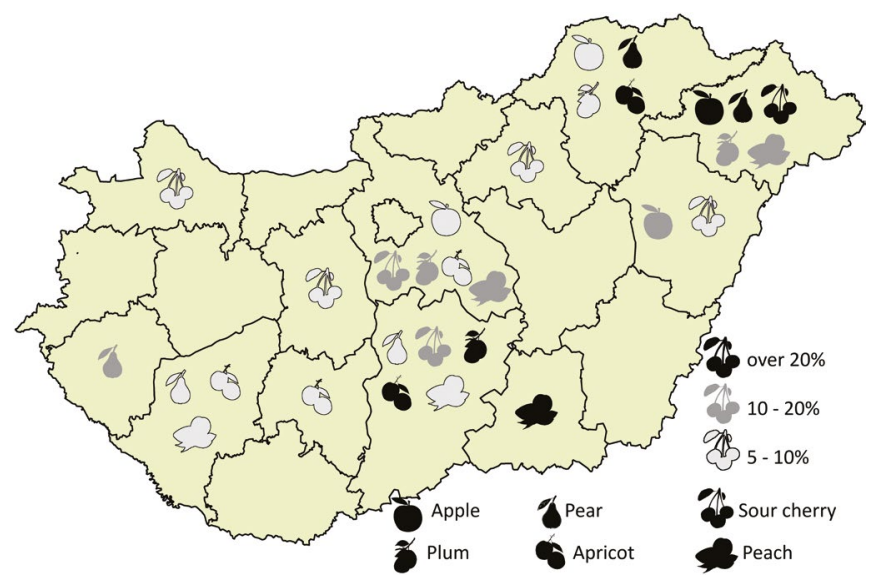

Fig. 14. Counties' shares in overall production of the main fruit species, 2018

Source: authors' own elaboration based on data from the Hungarian Central Statistical Office. 
asing competition. However, a reduction in the volume of wine produced need not necessarily be a bad trend. Under communism, quantity of wine dominated over quality, and that kind of situation could not continue in a competitive Common Market environment. Thus, while curbs on numbers of planted vines per ha and declined in amounts of grapes produced by each vine may look like straightforward volume reductions, the consequence can be and probably is wine of higher quality and greater value.

The period 1990-2020 also brought a decline in the area of the country supporting vineyards. The aforementioned trends (loss of traditional markets, a transition from quantity to quality) may have contributed to the abandonment to certain vineries, but (as the following section will make clear) a demand for continued urban development also represented an important driving force.

As was outlined at the beginning of the section, the crisis for livestock breeding was more prolonged than that involving crops, with total output only bottoming out in 2010, with a slow recovery to just around 60\% of the 1990 level (Fig. 5). That still in essence denotes a negation of all the increase achieved after the 1960s.

A key factor in Hungary's crop-livestock differentiation concerns the circumstances surrounding the relevant privatisations. Communist-era vertical integration involved central facilities engaged in animal breeding (at piggeries, in pens, at dairies, etc.), alongside supporting agricultural areas engaged in the production of fodder. However, the privatisation that came along often saw the latter privatised independently of the former, with none of the old vertical integration. This left it much more difficult to reorganise production. Also, with a steady rise in fodder prices, the competitiveness of livestock breeding was much reduced. Moreover, the specificities of the Common Agricultural Policy and shifts in domestic consumption also had a greater impact on livestock breeding.

As with crop production, different species were associated with different levels of decline (Fig. 15). In the case of fowl/poultry, a moderate reduction was followed by a relatively rapid recovery (50 million head in 1990 comparing with 39.7 in 2018); even as numbers of pigs kept have gone on falling (from 8 million in 1990 to 2.9 in 2018). This is in part a reflection of changing consumer habits: while the consumption of pork has decreased (1990 and 2018: 38.8 and $32.9 \mathrm{~kg} /$ capita respectively), that of poultry has increased markedly from 22.8 to $32.4 \mathrm{~kg} /$ capita in the above period. Moreover, stricter regulations have combined with increased fodder costs to compromise the viability of piggeries with just a few

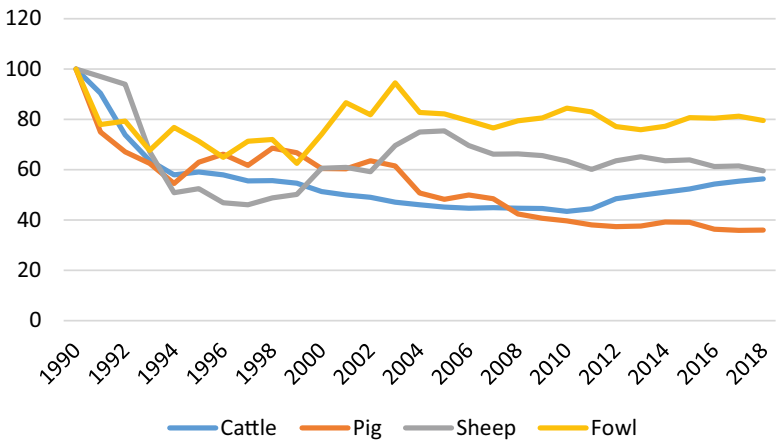

Fig. 15. Changes in livestock breeding in Hungary, 1990-2020 (1990=100\%)

Source: authors' own elaboration based on data from the Hungarian Central Statistical Office. 
animals. A large proportion of the swine originally kept in rural households as a traditional component of family farming were kept primarily in the context of self-sufficiency being achieved. However, the changing lifestyle of rural families led them to give up the most demanding and inconvenient aspects of agricultural activity first, including pig breeding. The consequences of keeping pigs (e.g. smell, and flies) may inconvenience neighbours, and are certainly less and less welcome even in the rural areas where they were once the norm. As the fourth section makes clear, the Hungarian Government has been intent on reversing this trend (by reducing tax and placing special emphasis within the Rural Strategic Programme framework), but success has proved rather elusive so far.

The consumption of beef plays only a secondary role in Hungary (2018: 3.3 kg/capita) as the primary aim of cattle breeding is dairying. The population of cattle was at its lowest ebb in 2010, and has been climbing slowly since that time (1990: 1,571,000; 2018: $885,000)$. This can be connected with a dynamically-increasing global demand for dairy products (Vőneki and Mándi-Nagy 2014), but the growing interest in traditional breeds (Hungarian grey cattle) has also facilitated this turnaround.

Fig. 16 reveals the rather even spatial pattern characterising livestock breeding. This is in line with fodder production nationwide, as well as its distribution at the end of the communist era. Another interesting observation is that unlike many (alpine) countries, Hungary has herds of cattle and sheep more connected with the Great Hungarian Plain than uplands. This reflects salt-affected areas being used as pasture.

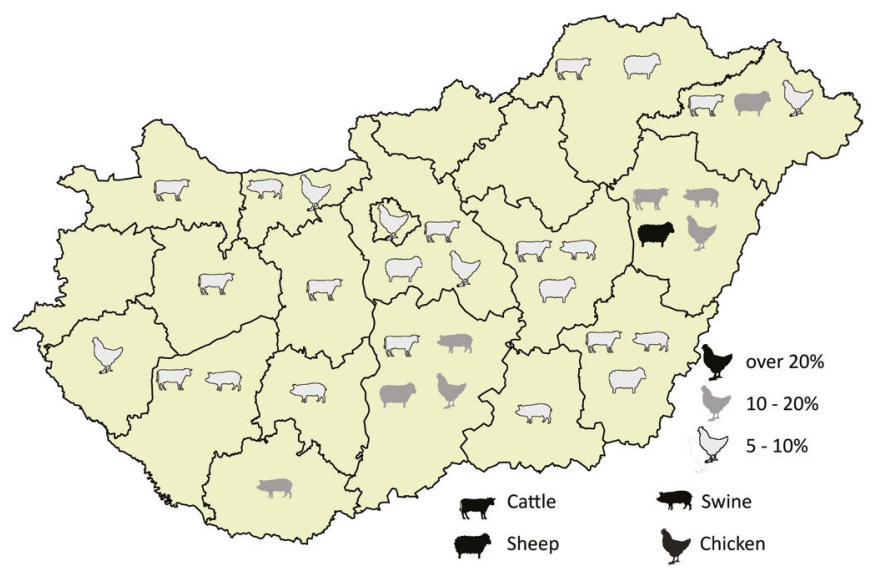

Fig. 16. The shares of cattle, swine, sheep and chickens, by county, 2019

Source: authors' own elaboration based on data from the Hungarian Central Statistical Office.

\section{Land use and sustainable agriculture in Hungary}

Like other European countries, Hungary has experienced a decline in the area of agricultural land as a key trend over the last 60 years. A main component of this is shrinkage in the area of arable land, gardens and grasslands. Statistics also point to accretion of land excluded from cultivation. Table 2 contains the changes by reference to the main land-use categories. 
Table 2. Land-use structure, 1990-2018

\begin{tabular}{|l|r|r|r|r|r|r|r|r|r|r|}
\hline \multicolumn{1}{|c|}{ Year } & $\begin{array}{c}\text { Arable } \\
\text { land }\end{array}$ & Garden & Orchard & Vineyard & $\begin{array}{c}\text { Grassland } \\
(\mathbf{1 0 0 0} \text { ha })\end{array}$ & Forest & Reed & Fishpond & $\begin{array}{c}\text { Built-up } \\
\text { area }\end{array}$ & Total \\
\hline 1990 & 4712.8 & 341.1 & 95.1 & 138.5 & 1185.6 & 1695.4 & 40.4 & 26.8 & 1067.5 & 9303.2 \\
2004 & 4510.3 & 96.8 & 102.6 & 94.5 & 1059.6 & 1823.4 & 61.5 & 33.6 & 1521.1 & 9303.4 \\
2018 & 4333.7 & 45.4 & 94.0 & 71.5 & 799.3 & 1939.7 & 35.5 & 36.6 & 1947.8 & 9303.4 \\
$2018-1990$ & -379.1 & -295.7 & -1.1 & -67 & -386.3 & 244.3 & -4.9 & 9.8 & 880.3 & \\
$2018 / 1990(\%)$ & 91.9 & 13.3 & 98.8 & 51.7 & 67.4 & 114.4 & 87.9 & 138.1 & 182.5 & \\
\hline
\end{tabular}

Source: authors' own elaboration based on data from the Hungarian Central Statistical Office.

Post-1990, these conversions were accelerated by the political and economic transition. While between 1962 and 1989, land-use changes affected some 25,000 ha a year, this value almost doubled to between 42 and 46,000 ha in the 1990-2012 period - according to Corine Land Cover Change data. Between 2012 and 2018, this rate of conversion declined to 31,000 ha a year, though this was obviously still a higher value than that noted pre-1990. A further decrease in the area of agricultural land is anticipated, not least as the goal of the Hungarian National Forest Plantation Programme is to raise the level of forest cover by an additional 750,000 hectares in the years to 2050. On the other hand, the demand to construct new built-up areas remains, while the main drivers of increase in the area covered by artificial surfaces are transformation and development in the economy, as well as a new suburbanisation period within the context of the urbanisation cycle. The modernisation and economic restructuring of Hungary, shifting poles of the economy and expansion of the transportation network have all inevitably required additional areas of land. The combined effect of economic restructuring and suburbanisation is most visible in the Budapest Functional Urban Area, though regional centres and larger county towns have also been greatly affected. It is in this region that more than $80 \%$ of land-use conversions start (with the transformation of agricultural land). However, Corine Land Cover Change also shows other areas of transformation. Data from the 1990-2000, 2000-2006, 2006-2012 and 2012-2018 databases - adapted to a 3x3 km reference grid point to a significant proportion of transformations not being associated with urban areas (Fig. 17). According to CLC Change, land-cover conversion occurred over 1.15 million ha of land in Hungary in the period 1990-2018, with 56\% of that (over 646,000 ha) taking place on the agriculture-dominated Hungarian Plain.

The two meso-regions particularly prone to conversion are Homokhátság and Nyírség. The former (the "Sand-ridge" in the Danube-Tisza Interfluve) is the Pleistocene alluvial fan of the Danube, while the Nyírség (in the Hungarian Plain's north-eastern part) is the alluvial fan of the Tisza. Both areas have weak, sandy soils with poor water-balance properties. The disadvantages are compensated for by the presence of labour-intensive agriculture, including vineyards, orchards and a diverse landscape with scattered farms. Moreover, both landscapes are vulnerable environmentally (partly due to the aforementioned limited capacity to retain water), with Homokhátság recognised as a zone of increasing aridity in the FAO's long-term forecast, to the extent that the most pessimistic assessments cannot even preclude desertification (UNCCD 2006).

If a closer look at Homokhátság is taken, a series of changes may be distinguished. Following the transition, the collapse of the market and disappearance of financial subsidies 


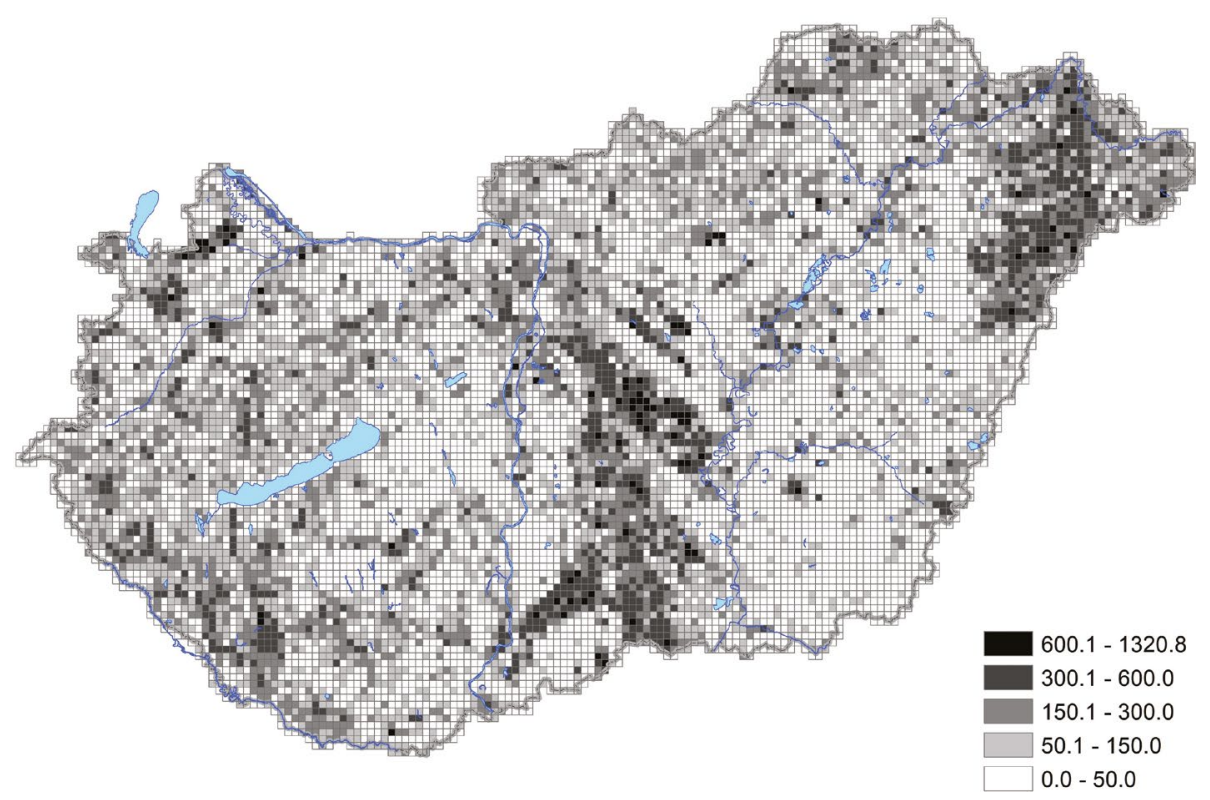

Fig. 17. Land-cover changes between 1990 and 2018

Source: authors' own elaboration based on Corine Land Cover Change, European Environment Agency, Copernicus Land Monitoring Service.

saw high-upkeep orchards and vineyards abandoned, and transformed into transitional woodland shrubs. Only in the second half of the 1990s did the government seek to resoIve this issue and have the former landscape restored. At first this effort involved refundable support, while later it relied on area-based subsidies, and finally targeted financial support for the restoration of vineyards and orchards, or even for the founding of new plantations. Following accession to the $\mathrm{EU}$, these schemes were straightforwardly prohibited, with a U-turn even ensuring that producers received support where they acted to cut down their plantations. This direction lasted through to 2010, only to followed by a period of the renewed founding of vineyards and orchards, with support again entailing a variety of financial constructs. These changes involving policy reversals only illustrate the ad-hoc nature of governance. Beyond this, the planting of forests has gained support since the early 2000s, even as it recognised that this objective may be not unambiguously positive (as alien species are planted, and may actually play a role in developing aridity). We can conclude that both the pre-2004 domestic subsidies and the CAP subsidies following accession contributed to a concentrating of land-use changes. This was a reflection of the fact that those farming on poor soils could only increase their revenues by maximising subsidies. But such a role for support payments is an unfavourable one that even the 2014 CAP reform did not resolve, such that incentives working against sustainability were continued with in some areas.

Békés, Bácska and Mezőföld provide some contrast, given the highly fertile nature of their soils. These areas are cultivated using the large-scale methods of "industrial agriculture". and land use here is stable, as income and subsidies taken together ensure sufficient profit for farmers. 
The appearance of organic farming and the cultivation of land in the aftermath of agro-environmental measures of the early 2000s represents a special case typifying Hungarian agriculture. At first, farmers welcomed these agro-environmental programmes and possibilities. By 2004 , some $25 \%$ of utilised agricultural land was encompassed by the agro-environmental programme. However, the bureaucratic system developing after accession to the EU caused some farmers to walk away with the ratio in steady decline from 2008 on. By 2017, only 8\% of utilised agricultural land was still subject to agro-environmental measures. The situation is worse in the case of organic farming. In contrast with the $\mathrm{EU}$, the rate has been rising much more slowly, and so is already lagging far behind (Fig. 18). In absolute terms this means that slightly more than 200,000 ha in Hungary are subject to organic farming. As of 2018, some 4000 farmers were involved in the production of agricultural goods of this kind.

The purposes of the NATURA 2000 network are to preserve biodiversity, and to maintain and restore the natural state of areas included, but also finally to ensure that cooperation between nature conservation and agriculture is achieved. In Hungary, 1.37 million ha (in 56 SPAs) are encompassed by the Birds Directive and 1.44 million ha (in $479 \mathrm{SCls}$ and SACs) under the Habitats Directive. The combined area is thus of 1.99 million ha (Fig. 19), though of that 39\% was actually under protection even previously (as every one of the country's protected areas, be it National Park, National Monument, minor Nature Reserve or Landscape Protection Site, comes under NATURA 2000). Other areas were designated in line with the presence of 105 species of animal other than birds, 91 species of bird, 36 species of plant and 46 types of habitat viewed as significant for conversation (Hungarian Central Statistical Office 2018; termeszetvedelem.hu).

Alongside agro-environmental measures, nature conservation and organic farming, it is also important to examine changes in the level of use made of fertilisers and pesticides - as a good indicator of agriculture's environmental footprint. Communist-era agriculture certainly featured the overuse of these chemicals. However, in line with the problems of the early 1990s already detailed - as well as the change of ownership and in farm-size structure - the old industrial approach to agricultural production weakened, with both

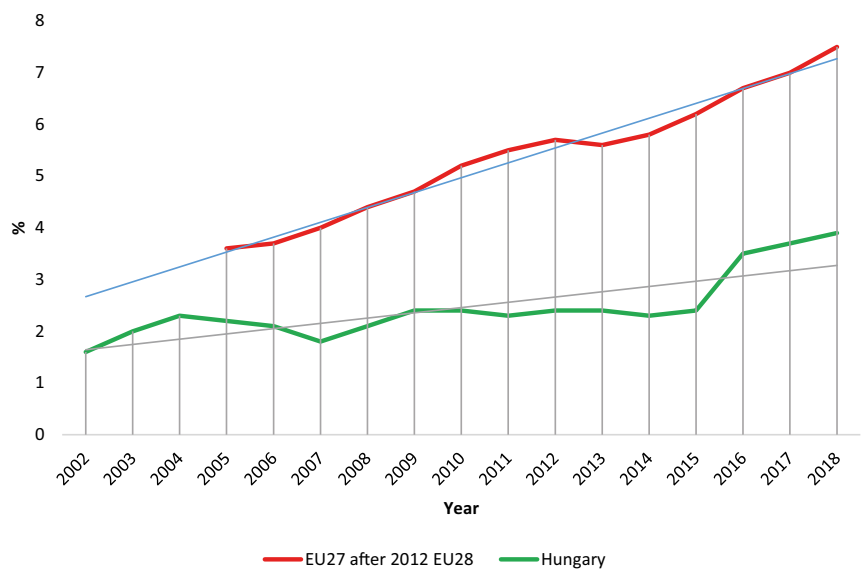

Fig. 18. Area under organic farming, 2002-2018

Source: authors' own elaboration based on data from Eurostat. 


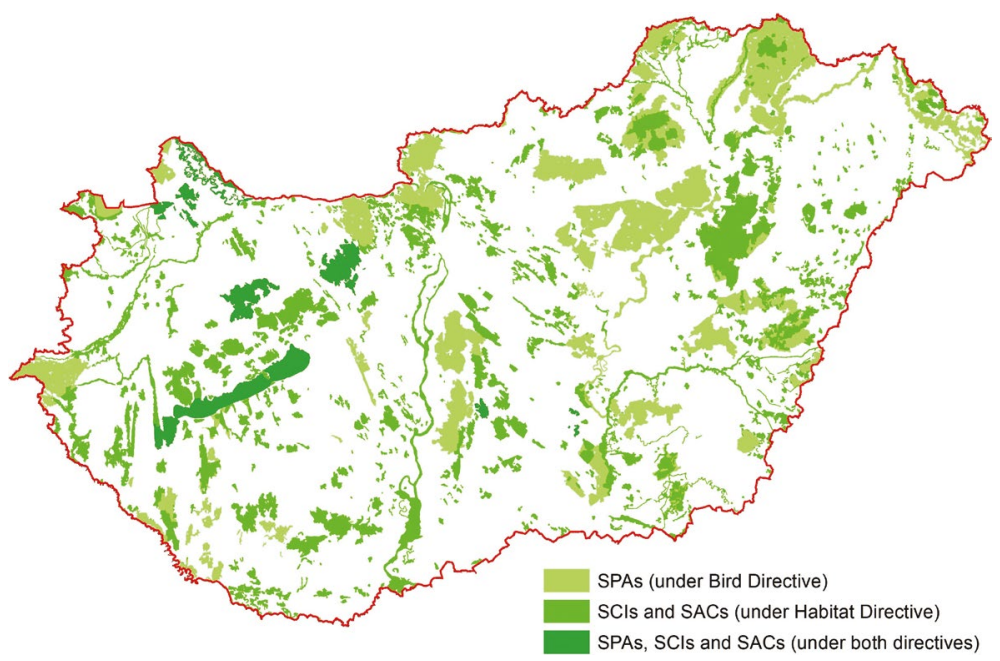

Fig. 19. Sites forming the Natura 2000 network in Hungary Source: European Environment Agency.

fertiliser and pesticide use also declining in consequence. While this process had a positive effect on the environment, it was also partly negative for the sector and its producers, as soil fertility for example declined, and with that yields. As had been anticipated, stabilisation of the sector combined with producers' improving financial situation, the growing significance of European subsidies and ongoing concentration of land ownership to permit a renewed increase in the use of chemicals. Fig. 20 makes it clear how relatively rapidly this process has been in the case of pesticides (in terms of the value of product sold).

The trend for the use of fertiliser has been somewhat different, as an increase in the early 2000s was followed by a 30\% reduction following the 2008 economic crisis. Thus sales grew from 355,000 t in 2000 to 630,000 t in 2019, which is "only" a 77\% increase (as opposed to the $500 \%$ increment noted for pesticide sales). Moreover, the use of orga-

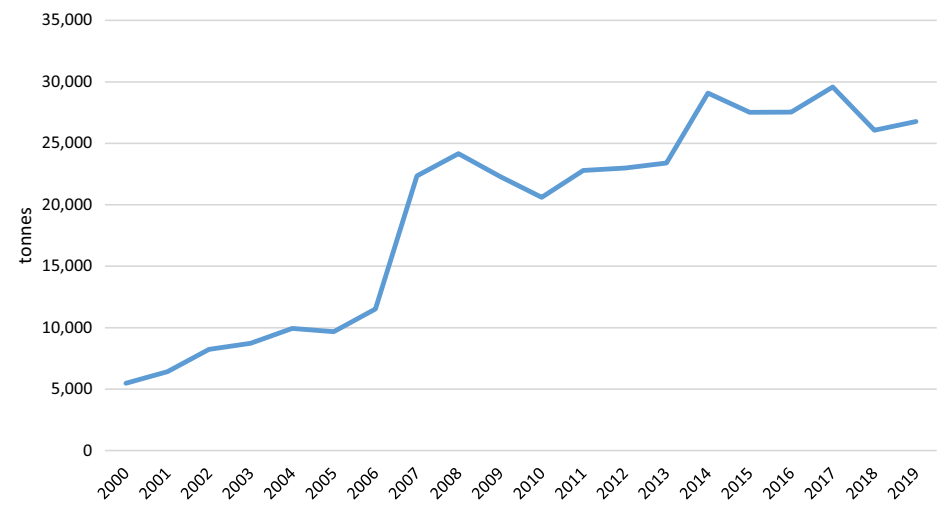

Fig. 20. Total sales of pesticides, $2000-2018$

Source: authors' own elaboration based on data from the Hungarian Central Statistical Office, Research Institute of Agricultural Economics. 
nic fertilisers and manures in Hungarian agriculture declined markedly during the period examined - in line with the decline in livestock numbers.

Change in populations of common farmland birds is an index deployed widely to measure agriculture's environmental impact. The processes described above did result in unfavourable changes in values for this index between 1999 and 2011. The agri-environmental database of Eurostat in fact notes a 26-point decrease for this index (Fig. 21). In fact, post-2011, it is either stagnation or a minimal improvement that is to be observed. Furthermore, it needs to be noted that a decline in populations of farmland birds is affecting Europe as a whole, even if things have not changed as rapidly as they have in Hungary. Overall, though, serious questions need to be posed as regards the effectiveness of the so-called greening of the CAP, as well as agri-environmental measures and indeed the NATURA 2000 programme itself. It is fairly obvious that future correction will be needed (European Court of Auditors 2017).

Since agriculture is a sector producing greenhouse gases, the relevant role in climate protection is an important one. Emissions reduced from $12 \mathrm{Mt}$ of carbon-dioxide equivalent (CDE) prior to the transition to $5,997,000$ t by 1995 . Emissions then oscillated around that value through to 2013; and then - after a moderate increase - the level reached $7,145,000$ t CDE - or $12 \%$ of Hungary's entire GHG emissions (equal to 58,559,000 t of $\mathrm{CDE}$, according to the EEA).

In connection with emissions of greenhouse gases, the usage of energy in agriculture also has to be taken into consideration. According to the KSH, as of 2010 the sector was only using $34.9 \%$ of the energy it had used back in 1989. This was probably the result of technological modernisation (Gockler 2013). The reduction is even more impressive, if account is taken of the way output from the cultivation of arable land rose significantly in the 2000s. However, data from Eurostat point to a reverse of this favourable process in the 2010s, with no less than a 32\% increase in energy consumption between 2010 and 2018 (Table 3).

Some general conclusions can be drawn where the processes referred to are concerned. The different national and European agricultural regulations and subsidies have diverse (and often unforeseen) environmental effects, and sometimes set off chain reac-

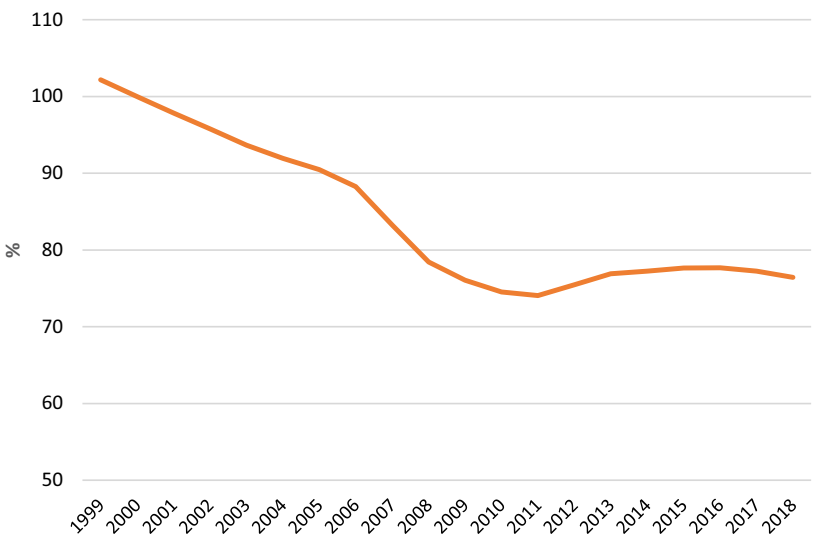

Fig. 21. Changes in the common farmland bird index, 2000-2018 (2000=100\%)

Source: authors' own elaboration based on data from Eurostat. 
Table 3. Final energy consumption by agriculture/forestry per ha of utilised agricultural area KgOE/ha

\begin{tabular}{|c|c|c|c|c|c|c|c|c|c|c|c|c|c|}
\hline & 2006 & 2007 & 2008 & 2009 & 2010 & 2011 & 2012 & 2013 & 2014 & 2015 & 2016 & 2017 & 2018 \\
\hline 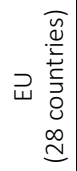 & 140.42 & 142.1 & 141.53 & $\mathrm{n} / \mathrm{a}$ & 147.02 & 143.53 & 143.56 & 146.05 & 143.32 & 140.3 & 146.1 & 148.01 & 159.13 \\
\hline $\begin{array}{l}\frac{Z}{0} \\
0 \\
00 \\
\\
\text { I }\end{array}$ & 94.65 & 85.79 & 90.97 & 76.31 & 91.25 & 90.42 & 74.6 & 97.56 & 110.94 & 107.83 & 121.03 & 113.87 & 119.94 \\
\hline
\end{tabular}

Source: Eurostat.

tions (as could be seen in regard to the Homokhátság case). Despite attempts at environment-friendliness, the current regulatory system in agriculture has generally been having an adverse environmental impact. This can only suggest further conflicts of interest between the agricultural sector and environmental protection.

\section{The role of the agricultural sector in the Hungarian economy}

As the previous section showed, agriculture has always been an integral part of the Hungarian economy, and indeed one responsible for the bulk of Hungarian exports at a number of different times in its history. As Table 4 shows, the radical reduction in agricultural output also left its mark on the share of GDP accounted for. The original high share dropped very quickly to just $5 \%$ of domestic production, before ceasing to change much more for no less than two decades. While this share is similar to that in most developed countries, the rapid reduction is far from the development in an organic direction taking place further west.

As in previous eras, the balance of trade in the agricultural sector has remained a positive one, with important export revenue for the country continuing to be provided. While the net volume of the trade in agricultural products increased post-1990, the sector's share declined by $15 \%$ in the case of exports, given the more-rapid growth achieved by other sectors (in fact as in other EU Member States). In the case of imports, the same trends can be observed: while volume also increased, the share of all imports accounted for declined. The fall of COMECON led to a shift in the main export markets: the role played by the

Table 4. An overview of the main economic indicators in agriculture and the food-processing industry, 1990-2018

\begin{tabular}{|l|c|r|c|c|c|}
\hline \multicolumn{1}{|c|}{ Indicator } & $\mathbf{1 9 8 9 / 1 9 9 0}$ & $\mathbf{1 9 9 7}$ & $\mathbf{2 0 0 4}$ & $\mathbf{2 0 1 1}$ & $\mathbf{2 0 1 8}$ \\
\hline Share (\%) of GDP (due to agriculture, forestry and fisheries) & 13.7 & 5.9 & 5.0 & 4.4 & 4.2 \\
\% of export accounted for by food products & $22.4^{*}$ & 15.0 & 5.9 & 7.5 & 6.8 \\
\% of import accounted for by food products & $6.4^{*}$ & 5.1 & 3.7 & 5.3 & 5.2 \\
\hline
\end{tabular}

*1993 data

Source: authors' own elaboration based on data from the Hungarian Central Statistical Office, Statistical Yearbook of Hungary (1990, 1993), Pocketbook of Agriculture (2001). 
Soviet Union (and later the Commonwealth of Independent States) decreased, while the significance of the EU15 (53\% in 1991) increased. Through to 2004, another important trend was the increase in the share of agricultural exports accounted for by the Centraland South-eastern European countries (CEFTA) (1991: 5\%, 2001: 20\%).

Following Hungary's accession to the EU, the general output from agriculture was able to keep up with growth in the economy in general, while the share of GDP accounted for by agriculture stabilised at a level around $4 \%$. The share taken by food products among exports and imports remained largely the same, while the difference between them decreased somewhat. While the trade balance for food products remained positive after 2013, a nominal reduction in the surplus is observable.

Following the 2007 EU enlargement (including Romania and Bulgaria), the overwhelming majority (82\%) of Hungary's agricultural exports in 2008 were directed at the European Union, with 50\% going to the old Member States (the EU-15), and 32\% to newly-acceded ones. Russia played only a marginal role as a destination for exports, taking just a $4 \%$ share. Through to 2018, there was an increase in the share of Hungarian exports taken by the EU (85\%). This growth can be attributed to the accession of Croatia, and to the growing importance of new Member States. Russia, as the main former export partner, received only a $2.4 \%$ share of Hungary's 2018 export.

This generally positive picture is threatened by two future challenges: the unfavourable change of the agricultural price scissor and climate change. The scissor displays the change in agricultural producer prices in comparison with that affecting costs of production. Where costs are rising faster than prices the scissor "opens", with the profitability of agricultural activity reducing, and farmers thus facing economic hardship.

The increasing production costs after the Oil Crisis represented a key reason behind the agricultural stagnation of the 1980s. As Fig. 22 indicates, the opening of the scissor is a long-term challenge facing agriculture. While this situation may facilitate innovation, it also contributes to the concentration of holdings (economies of scale), and leaves farmers more dependent on additional sources of revenue.

As section two shows, climatic conditions in Hungary are ideal for the production of a wide variety of agricultural products. However, the results of research by the Hunga-

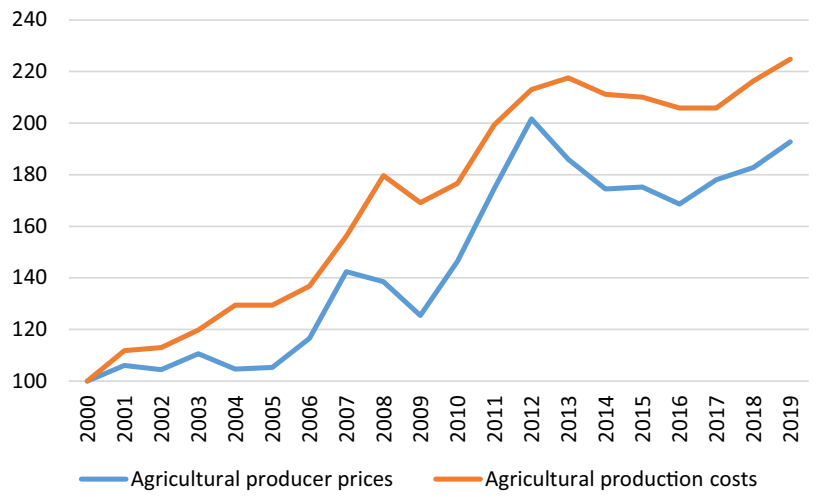

Fig. 22. The agricultural price scissor: changes in agricultural producer prices and production costs, 2000-2019, $2000=100 \%$

Source: authors' own elaboration based on data from the Hungarian Central Statistical Office. 
rian Meteorological Service (OMSZ) (2017), suggest that climate change may indeed put these favourable conditions at risk. Adverse changes will see a deterioration as regards both temperature (higher on average and with more heatwave days) and precipitation (a change of distribution through the year). Knock-on consequences will be more-frequent periods of drought, but also increased intensity of rainfall when it does occur and a decline in the length of the winter period of snow cover through to possible elimination altogether). In addition, the OMSZ anticipates the more-frequent occurrence of extraordinary, extreme weather events such as rainstorms, windstorms, and hail. Gaál and colleagues (2014) calculated that, for the period up to 2050, the effect of climate change might even be positive for certain crops over the largest area (see Fig. 23). Equally, for the period 2071-2100 it is a clearly negative picture for the crop-production sector that emerges.

Research shows that Hungarian farmers are aware of the above challenges, whose signs are already being perceived. At the same time information continues to be in short supply, especially as regards possibilities for adaptation (Farkas and Hoyk 2017). The search for a way out can also be perceived on the government side, though so far the main thinking entails the reconstruction of irrigation clusters built under communism and not used following the regime change, as well as a comprehensive programme for the development of irrigation (MADOSZ 2020). The EU is prioritising the proliferation of digital or precision-farming technologies (Takácsné et al. 2018; EC 2018), as these can help to mitigate the effects of climate change.

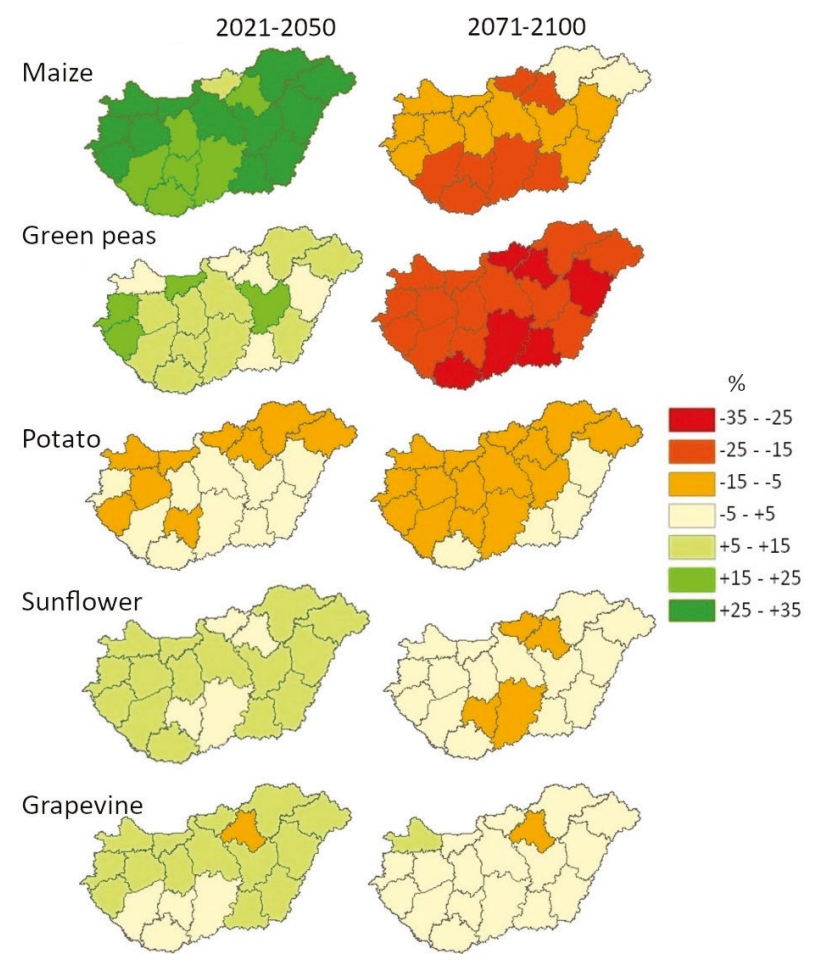

Fig. 23. Expected changes in crop yields compared with the 2002-2011 averages Source: Gaál et al. (2014). 


\section{Rural societies in the shadow of agricultural transformation}

As the historical overview section made clear, Hungary remained an agro-industrial country even after the second Industrial Revolution, and while the forced industrialisation and agricultural collectivisation of the communist era drove hundreds of thousands of people out of agriculture, there were still more than half a million people employed directly in farming at the start of the study period. However, like other indicators discussed, this one experiences declines in value very abruptly - on account of the crisis and the reorganisation of agriculture (Table 5).

It also has to be added that the services connected to agricultural activity and ancillary enterprises operated by the former era's State Farms and Cooperatives also lost their footing after the transition. Their collapse also contributed to rural unemployment, with a large number of rural employees losing their jobs - in what represented one of the major challenges facing post-communist governments. The situation faced by rural societies was a perilous one. Because of their generally low levels of education and disadvantaged employment situations, the unemployed faced a limited number of choices. Many escaped into some state welfare support for example involving a disability pension. So that the stress on the job market might be reduced, this was even encouraged for the partially disabled as well. Another large group of people fell into the trap of long-term unemployment. The areas hit hardest by the agricultural and industrial downsizing often overlapped, with persistent zones of crisis thus taking shape.

After the EU accession, employment in the agriculture and food-production industry seemed to stabilise at around $8 \%$ of total employment. However, it must be added that the actual number of people involved in agricultural activity may be much higher than the official employment figure implies. For example, the ÁMÖ of 2016 counted 114,000 full-time employees ( 97,000 employed by legal entities), as well as 128,000 seasonal employees (57,000 employed by legal entities). However, data collection also revealed that family workforces on private holdings (i.e. the farmer plus family members effectively engaging in unpaid agricultural activity during the previous year) amount to some 711,000 people.

Mention should also be made of the fact that many households not reaching the threshold for farms according to the ÁMÖ still engage in some agricultural activity (as of 2016, such households were cultivating almost 30,000 ha of land and keeping almost 3 million birds). The conclusion has thus been that - despite relatively low numbers in employment - agricultural activity continues to play an important part in the life of a significant share of the rural population (around 4 million people - if the delimitation adopted by the Rural Development Programme of 2014-2020 is to be accepted).

Table 5. Employment in agriculture and the food-processing industry, 1990-2018

\begin{tabular}{|l|c|c|c|c|c|}
\hline \multicolumn{1}{|c|}{ Indicator } & $\mathbf{1 9 8 9 / 1 9 9 0}$ & $\mathbf{1 9 9 7}$ & $\mathbf{2 0 0 4}$ & $\mathbf{2 0 1 1}$ & $\mathbf{2 0 1 8}$ \\
\hline Employed in agriculture, forestry and fisheries ('000s) & 693 & 288 & 205 & 185 & 215 \\
Employed in the food industry ('000s) & 234 & 160 & 141 & 124 & 144 \\
Share of overall employment (\%) & 19 & 12.29 & 8.87 & 8.1 & 8 \\
\hline
\end{tabular}

Source: authors' own elaboration based on data from the Hungarian Central Statistical Office, Statistical Yearbook of Hungary (1990), Pocketbook of Agriculture (2001). 
However, additional data point out that only a small fraction of such people can make any kind of a living out of agricultural activity. The National Tax Administration distinguishes agricultural income from small-scale production (licensed traditional or otherwise) as a basis upon which to impose personal income tax. As of 2018, that type of agricultural income accounted for only $0.3 \%$ of the total income liable to personal income tax (i.e. some $130 \mathrm{M}$ Euros). The share of small-scale farming in total income exceeds $10 \%$ in the cases of just 17 settlements, mostly small villages. On the other hand, there are more than 1000 municipalities in which no income from small-scale farming is earned in official terms. In conclusion, earnings from small-scale farming make up only a sliver of total domestic income in most municipalities, while remaining important in just a handful of villages.

When it comes to data on financial support from the Hungarian State Treasury, it can be noted how some 150,000 recipients were in receipt of area-based subsidies as of 2019 (a notable reduction from the 182,000 in 2015). Even so, agricultural subsidies are amongst the most important transfers directed at rural areas, hence the expectation that these will strengthen local economies and facilitate the development of areas lagging behind. A study by the State Audit Office of Hungary (Állami Számvevőszék 2015) reveals that, while around 10 billion Euros were paid out as direct subsidies between 2007 and 2014, the sources available in the New Hungary Rural Development Programme during the same period only amounted to around 5.5 bn Euros. However, as other researchers have pointed out already, a significant share of area-based payments is "exported" from rural areas to urban centres, not therefore proving of benefit to local communities (Kovách 2012). Moreover, the latter must still face the negative effects of direct payments, such as the concentration of land ownership and rapid increase in land purchase and rental prices (Hungarian Central Statistical Office 2016). Since extensive crop production with modern machinery requires only a few days of local activity a year, farmers on large holdings may even live far from their village. This kind of agricultural production does not provide employment opportunities for locals, with the profit and even the agricultural subsidies not appear in their localities either.

As with Western European experiences of rural restructuring, a reduction in the level of importance of agricultural production as regards the employment and livelihood of rural inhabitants has taken place, even as there was an increase in the symbolic significance of agricultural activities (Marsden et al. 1990). Some distinguished aspects of agriculture came to operate as identity-forming features at both local and national level. Local- and central-government actors often tried to facilitate the process (later with the help of EU funding), with more or less success. Thematic routes (especially wine routes) were developed, alternative rural tourism is growing in popularity, and some relatively untouched areas with a harmonious landscape of agricultural and natural features have been discovered by amenity migrants (Fejős and Szijártó 2002). These processes helped revitalise some laggard areas, and to rejuvenate depopulating communities. This post-fordist transformation is not without conflicts, however, as some less-desirable aspects of agriculture (like pig breeding) often find themselves contested by those pursuing rural activity of the new type. 


\section{Conclusion}

By examining the agricultural transformation from several different aspects, this part seeks to highlight the most important development trends in Hungarian agriculture between 1990 and 2020. As was discussed in the second section (Study area, materials and methods), research methods by which to achieve this have included secondary analysis of statistical data and also GIS data analysis. The second section also revealed how natural conditions here generally favour agricultural activity, even as they also incentivise spatially diverse patterns of production.

The historical overview provided by the third section discussed the origin of certain characteristics still influencing agricultural production (the settlement network of the Great Hungarian Plain, the scattered farm system, the regulation of waters and spatial production structures). Processes unfolding during the communist era were discussed at more length. As was noted, the second attempt at collectivisation saw the Soviet model of State Farms and Cooperatives adapted with compromises (e.g. household plots) that allowed for more flexibility and competitiveness. In the wake of initial investments, Hungarian agriculture experienced unprecedented growth in the 1960s and 1970s, and can be (still is) considered a success story for state socialism. However, by the mid-1980s, the inner reserves available to that system had depleted, such that agriculture entered a period of stagnation years prior to the political and economic transition.

The section in question also revealed how, through to the $19^{\text {th }}$ century, agricultural development in Hungary mostly embraced the country's natural physical diversity. That led to regionally-differentiated patterns, with each locality seeking to best utilise its environmental conditions. Historical events offered further impetus for differentiation. However, the onset of the regulation of watercourses signified a markedly different approach, whereby the focus was on changing environmental conditions, rather than adapting to them. The communist regime was also prone to environmental nihilism, the (attempted) draining of the Hanság area being a prime example. The negative consequences of this approach often emerged only decades later, e.g. the presence of excess inland water and salinification on former floodplain areas. The loss of the old wetlands may further strengthen the effects of the impending climate change.

As was discussed in the fourth section (on the changing legislative framework relating to agriculture), the post-1990 dismantling and privatisation of communal property was one of the major challenges characterising the transition to a social market economy. The means had to be in a position to address past violations and damage perpetrated by the state. In agriculture, this was a particularly sensitive task, as the Independent Smallholders' Party was part of the newly-elected democratic government, and was committed to reviving the peasant farms. The privatisation of the sector and completion of the compensation process took seven years, but its consequences remain in place today. At the end of the process, a highly-fragmented farm structure was developed, with farms often operating as forced enterprises. These characteristics represented strong barriers to the sector's development. To join the European Union and permit Hungarian agriculture to match competition within it, an EU-conforming support system was launched in the late 1990s, only to be replaced by CAP support schemes from 2004. According to the Ministry of Agriculture, the most-major obstacle to development today is undivided common land ownership, which took shape as a result of the compensation and privatisation 
process. The legislation to eliminate this was passed by the Hungarian Parliament in the middle of this year.

After the political and economic transition, legislation on Hungarian agriculture tried to satisfy multiple needs, i.e.: to compensate for historical injustice, to help soothe the economic crisis in rural areas, to preserve (or restore) competitiveness in the farming sector, and to promote more environment-friendly land use and agriculture. Since these goals (at least partly) contradicted each other, it was obvious from the outset that there would be some shortcomings in the legislative framework. Moreover, its freedom was limited by two factors: the generally poor state of the economy and the legislative needs and demands imposed by the EU.

As was discussed in the fifth section (on changes of ownership and the structure of agricultural holdings), the first decades of privatisation and compensation saw an evening-out of the share of private and legal holdings within the cultivated area. In the following two decades, the overall number of private holdings declined rapidly (2000: 958,534; 2016: 421,870 ), while the number of private holdings with more than 10 ha of utilised agricultural land increased. As the historical overview also showed, Hungarian agriculture can be described by reference to phases of the concentration and deconcentration of land. The concentration period through to the Second World War was followed by a radical process of land redistribution. However, the communist-era reorganisation also led to concentration, albeit within a different structure. The results of the compensation following the transition pointed to deconcentration. However, as could be seen clearly, the processes of recent decades once again indicate ongoing concentration of land. The current concentration of ownership is high compared with in other European countries. As of 2010, the share of farms of over 500 ha within the total area of arable land surpassed the percentage managed by large estate in this size category prior to World War II (Kovách 2016). It is important to note that the current laws in force limit the maximum size of owned land to 300 ha per person, while the maximum are for cultivation is 1200 hectares. However, there are some loopholes that hinder the effective enforcement of this regulation. Equally, the public and political debate over preferred ownership structure is still not settled, with practical and ideological arguments on both sides (regarding economies of scale, rural employment, the prestige of the independent small-scale farmer, etc.).

The sixth section discussed post-communist changes and current characteristics of production structure in the agriculture sector. As can be noted, the political and economic transition was immediately followed by a dramatic decline, even if crop production and livestock breeding followed different pathways. After the initial plunge, crop production output started to rise again rapidly, such that by the early 2000s it surpassed the output of the communist era. The crisis in livestock breeding was more prolonged. When it reached its minimum in the early 2010s, output was comparable with that in the early 1960s. While the production of certain crops (e.g. maize and oilseeds) increased greatly, others (like sugar beet) lost their former significance. Variations can also be observed in the case of different species of livestock: the dramatic reduction in the pig population could be set against the poultry sector that fared relatively more favourably. The factors behind the differing trends are various: from market loss, increasing competition and unprofitable production, through changing global trends, domestic consumption habits and the rural lifestyle, to the probable first signs of climate change. As could be noted, certain clear spatial patterns of production can be discerned, and are seen to be gov- 
erned by both natural conditions and the heritage of history. While the overall spatial patterns have changed little over the last thirty years, agriculture's uneven development puts a strain on the historical division of labour and can have a significant negative impact on regions that traditionally relied on sectors faring less well.

As section seven discussed, Hungary resembles many other European countries in having experienced a decided decline in the area of agricultural land. Within this process, the decreases in arable land and the area of pastures look most significant in absolute terms. And, as in the communist era, the main driver of decrease in the examined period is the extension of built-up areas. The rapid loss of agricultural land due to urban sprawl is in fact raising concerns all over Europe. However, the demographic forecasts predict persisting suburbanisation and a further increase in the population of the agglomeration ring of Budapest. Future conflict of interest makes the necessary steps to limit urban sprawl much harder to take. However, as climate change also threatens agricultural productivity in the long term, it is of the utmost importance that agricultural land be retained. Over the examined period, the loss of agricultural land was not yet accompanied by a fall in crop-production output, so the decline in the decade from 1990 on led to a situation in which intensified production was the determining factor - as also therefore supported by increased sales of fertilisers and pesticides, as well as a growing demand for energy in the sector. As a result, the negative environmental impacts associated with farming are also intensifying, as is evidenced by declines in numbers of farmland birds, and an inclination for the effectiveness of agri-environmental support schemes to be called into question. Unfortunately, the spread of organic farming in Hungary is very slow, and other processes in the sector (the development of large-estate systems and labour shortages) are also inhibiting the spread of this mode of cultivation.

Section 8 revealed that, despite a drastic reduction in agriculture's share of GDP, a key role in the Hungarian economy has been retained. As in previous eras, the trade balance for the agricultural sector remained positive throughout, providing important export revenue for the country. As was discussed, the position of agriculture in the Hungarian economy is now stabilised following an initial shock. However, balance might still be upset by the long-term unfavourable changes of the agricultural price scissor, as well as climate effects.

Section 9 discussed the effect of the agricultural changes in the rural society. It has been revealed that, while official numbers in employment fell the reality remains one in which a much larger share of the (mostly) rural population is connected with agricultural activities at some level. However, once again, only a small proportion of these people obtain significant income from this. A notable share of the direct agricultural subsidies are "exported" out of the countryside, with spill-overs therefore limited, and further rural development not facilitated. Another recent phenomenon is the post-productivist reinvention of rural areas, assigning symbolic meaning to certain farming activities and ensuring the significant role played by the rejuvenation of certain rural communities. However, the driving forces are far too weak to allow a country-wide rural renewal to be initiated.

The most important lesson to be drawn from our summary is that the economic and social environment in Hungarian agricultural production has changed dramatically over the last 30 years. The changes referred to have been both positive and negative, but their most important result is a diminution of agriculture's importance both locally and nationally. Despite this, it is hard not to view agriculture as an important part of both the 
economy and the image of the country (e.g. through hungaricums like winter salami and paprika). While the post-2020 CAP reform may bring further significant change in the regulatory environment, the most major challenge for farmers in the medium to long terms may still be climate change. In terms of effects, we do not yet see these with complete clarity, even as it is likely that significant further transformation in both the means and structure of production will ensue. Based on these, the fate of Hungarian agricultural production seems to be (and have been) one of continuous transformation and change throughout the time since the beginning of the $20^{\text {th }}$ century.

\section{Acknowledgement}

Publication prepared under the research projects of the National Science Centre, no. UMO-2016/23/B/HS4/00421, Models of agriculture transformation in the countries of Central and Eastern Europe after the fall of the Eastern Bloc - review of achievements, determinants and development scenarios.

\section{References}

Agricultural Censuses of the Hungarian Central Statistical Office. (2000-2016). https://www.ksh.hu/ agrarcenzusok_gszo, https://www.teir.hu/(30.07.2020).

Agricultural Yearbook of Hungary. (1987). Budapest: Hungarian Central Statistical Office.

Állami Számvevőszék. (2015). Tanulmány a 2007-2013 évi EU költségvetési időszakban Magyarország részére juttatott közösségi támogatások összefoglaló bemutatásáról, értékeléséröl. https:// www.asz.hu/storage/files/files/Publikaciok/Elemzesek_tanulmanyok/2015/2007_2013_eu_ koltsegvetesi_idoszakban_magyarorszag_reszere_juttatott_kozossegi_tamogatasok_osszefoglalo_bemutatasa_ertekelese.pdf? ctid=855 (30.07.2020).

Bellon, T. (1996). Ártéri gazdálkodás az Alföldön az ármentesítések előtt. In: Frisnyák S (ed.) A Kárpát-medence történeti földrajza) (p. 311-321). Nyíregyháza, MTA Szabolcs-Szatmár-Bereg Megyei Tudományos Testülete.

Beluszky, P. (2001). A Nagyalföld történeti földrajza. Budapest-Pécs: Dialóg Campus Kiadó.

Bobvos, P. (1996). Az aranykorona és a termőföld-érték. Acta Universitatis Szegediensis de Attila József nominatae, Acta oeconomica, 1, 73-82.

Bódi, F., Savova, R. (2018). A bolgárkertészek Magyarországon a 19. század végén és a 20. század első felében - környezeti és gazdaságantropológiai aspektusból. Magyar Tudomány, 179(3), 373-382. https://doi.org/10.1556/20 65.179. 2018. 3.7

Burger. A. (2001). Agricultural development and land concentration in a central European country: a case study of Hungary. Land Use Policy, 18(3), 259-268. https://doi.org/10.1016/ S0264-8377(01)00023-0

Copernicus Land Monitoring Service. (2020). https://land.copernicus.eu/(30.07.2020).

Corine Land Cover Change. (1990-2020). https://land.copernicus.eu/pan-european/corine-land-cover (30.07.2020).

Csáki, C., Lerman, Z. (1997). Hungarian Land Reform and Farm Restructuring. EC2AU Policy Note (Draft), Washington DC: The World Bank, https://www.researchgate.net/publication/304936397_Hungarian_Land_Reform_and_Farm_Restructuring (30.07.2020). 
Domán, C., Péter, K. (2018). Pénzügyi hírlevél, 11, 4. Budapest: Research Institute of Agricultural Economics.

EC. (2018). https://eur-lex.europa.eu/legal-content/EN/TXT/? uri=SWD: 2018:301:FIN (30.07.2020).

Enyedi, G. (1988). Spatial diffusion of innovation in Hungarian agriculture, In: E. Orosz (ed.), Spatial organization and regional development, Papers of the 6th Polish-Hungarian seminar, Stare Pole, 1986. Discussion Papers (123-148). Pécs: Centre for Regional Studies.

Erdész, F., Jankuné, K., Kozak, A., Radóczné, K. (2009). A zöldség- és gyümölcságazat helyzete. Budapest: Research Institute of Agricultural Economics.

European Court of Auditors. (2017). Greening a more complex income support scheme, not yet environmentally effective. https://www.eca.europa.eu/Lists/ECADocuments/SR17_21/SR_GREENING_EN.pdf (30.07.2020).

European Environment Agency. (2020). https://www.eea.europa.eu/(30.07.2020).

EUROSTAT. (2000-2018). https://ec.europa.eu/eurostat/(30.07.2020).

Farkas, J., Hoyk, E. (2017). Climate consciousness and adaptation from the viewpoint of farmers. Journal of Agricultural and Environmental Sciences, 4(1) (Suppl.), 137-142.

FEFAC. (2019). Annual Report 2018-2019. Brussels: FEFAC.

Fejős, Z., Szijártó, Z. (2002). Egy tér alakváltozásai: esettanulmányok a Káli-medencéröl. Budapest: Néprazi Múzeum.

Földmúvelésügyi Minisztérium. (2012). Darányi Ignác terv a Nemzeti Vidékstratégia (NVS 2012-2020) végrehajtásának keretprogramja. http://videkstrategia.kormany.hu/download/4/ ae/40000/DIT2_magyar_t\%C3\%B6rdelt_120910.pdf (30.07.2020).

Gaál, M., Quiroga, S., Fernandez-Haddad, Z. (2014). Potential impacts of climate change on agricultural land use suitability of the Hungarian counties. Regional Environmental Change, 14, 597-610. https://doi.org/10.1007/s10113-013-0518-3

Gockler, L. (2013). Energiafelhasználás a mezőgazdaságban. Mezőgazdasági Technika. http:// technika.gmgi.hu/uploads/termek_425/energiafelhasznalas_a_mezogazdasagban_13_12.pdf (30.07.2020).

Hungarian Central Statistical Office. (2016). Statisztikai Tükör - Mezőgazdasági termőföldárak és bérleti dijak, 2015. http://www.ksh.hu/docs/hun/xftp/stattukor/mgfoldarak/mgfoldarak15.pdf (30.07.2020).

Hungarian Central Statistical Office. (2018). A fenntartható fejlődés indikátorai Magyarországon. http://www.ksh.hu/docs/hun/xftp/idoszaki/fenntartfejl/fenntartfejl18.pdf (30.07.2020).

Hungarian Central Statistical Office. (1990-2020). https://www.ksh.hu (30.07.2020).

Isépy, A., Losonczi, T., Szente-Orbán, C., Ecsediné, W. (2018). Agrárpiaci jelentések - Zöldség. Gyümölcs és Bor, 22(15). Budapest: Research Institute of Agricultural Economics.

Juhász, P. (2001). Az agrárcsoda vége és a tulajdonreform. Beszélö, 2. http://beszelo.c3.hu/01/02/ 05juhasz.htm (30.07.2020).

Kapronczai, I. (ed.). (2010). A magyar agrárgazdaság az adatok tükrében az EU csatlakozás után. Agrárgazdasági Információk, 12. Budapest: Research Institute of Agricultural Economics.

Kovách, I. (2012). A vidék az ezredfordulón: A jelen-kori magyar vidéki társadalom szerkezeti és hatalmi változásai. Budapest: MTA Tár-sadalomtudományi Kutatóközpont Szociológiai IntézetArgumentum Kiadó.

Kovách, I. (2016). Földek és emberek. Földhasználók és földhasználati módok Magyarországon. Budapest: MTA TKI-Debreceni Egyetemi Kiadó.

Kovách, I. (2018). Földhasználat és földtulajdon-szerkezet. In: T. Kolosi T, I. Tóth (eds.), Társadalmi Riport 2018 (248-263). Budapest: TÁRKI. 
Krajkó. G., Mészáros, R. (1984). Bács-Kiskun megye gazdasági földrajza. Kecskemét: Bács-Kiskun Megyei Tanács.

Laszlovszky, J. (2006). Földmúvelés és állattenyésztés a középkori Magyarországon. In: M. Gyöngyössy (ed.), Magyar középkori gazdaság- és pénztörténet: Jegyzet- és forrásgyújtemény (53-80). Budapest: Bölcsész Konzorcium.

MADOSZ. (2020). http://madosz.hu/news/view? id=12124 (30.07.2020).

Marsden, T., Lowe, P., Whatmore, S. (1990). Rural Restructuring: Global Processes and Their Responses. London: David Fulton.

Mester, Z., Rácz, B. (2010). The spread of the Körös Culture and the raw material sources in the northeastern part of the Carpathian basin: a research project. In: J. Kozlowski, P. Raczky (eds.), Neolithization of the Carpathian Basin: Northernmost distribution of the Starcevo/Körös culture (23-35). Kraków: Polska Akademia Umiejętności.

Molnár, I. (1997). A mezőgazdaság helyzete és arányai a nemzetgazdaságban. In: I. Kollega Tarsoly, I. Bekény, D., Dányi (eds.). Magyarország a XX. században II. Kötet (517-522). Szekszárd: Babits Kiadó.

NAK. (2016). Agrár-környezetgazdálkodás. Kézikönyv a támogatási kérelem benyújtásához. http:// nak.hu/kiadvanyok/kiadvanyok/130-akg-kezikonyv/file (30.07.2020).

NAK. (2018). Erősödő agrár- és élelmiszergazdaság, jólétében gyarapodó vidék. http://nak.hu/kiadvanyok/kiadvanyok/2301-erosodo-agrar-es-elelmiszer-gazdasag-joleteben-gyarapodo-videk/ file (30.07.2020).

Napi.hu. (2020). https://www.napi.hu/magyar_gazdasag/dontottek-vege-az-osztatlan-kozosfoldtulajdonnak.709232.html (30.07.2020).

OECD - FAO. (2019). OECD -FAO Agricultural Outlook 2019-2028, Paris - Rome: OECD Publishing. http://www.fao.org/3/ca4076en/ca4076en.pdf (30.07.2020).

OH. (2017). https://www.parlament.hu/documents/10181/1202209/Infojegyzet_2017_33_osztatlan_kozos_tulajdon.pdf/056a8f83-1665-42f7-9715-a688736f573a (30.07.2020).

OH. (2019). https://www.parlament.hu/documents/10181/1789217/Infojegyzet_2019_7_agrartamogatasok.pdf/6ae0b71a-a535-8ca7-25e5-9dee2b3f38b4 (30.07.2020).

OMSZ. (2018). Climate change - observed changes - Hungary. https://www.met.hu/eghajlat/ eghajlatvaltozas/megfigyelt_valtozasok/Magyarorszag/(30.07.2020).

Pocketbook of Agriculture. (2001). Budapest: Research Institute of Agricultural Economics.

Pongrácz, T. (1997). Compensation (Kárpótlás). In: I. Kollega Tarsoly, I. Bekény, D. Dányi (eds.), Magyarország a XX. században II. Kötet (689-697). Szekszárd: Babits Kiadó.

Popp, J., Harangi-Rákos, M., Oláh, J. (2018). A napraforgó és repce vertikum versenyképességének kilátásai. Journal of Central European Green Innovation, 6(1), 75-108.

Ruby, R., Senthold, A., Richard, R., Athanasios, P., Gerrit, H., Roberto, Q., Guy, H., Joost, W. (2018). Climate change impact on global potato production. European Journal of Agronomy, 100, 87-98. https://doi.org/10.1016/j.eja.2017.11.008

Statistical Yearbook of Hungary. (1990). Budapest: Hungarian Central Statistical Office.

Statistical Yearbook of Hungary. (1993). Budapest: Hungarian Central Statistical Office.

Takács, J. (2005). A magyar parasztság sorsfordulói, 1514-2003. Budapest: Agroinform Kiadó.

Takácsné, G., Lámfalusi, I., Molnár, A., Sulyok, D., Gaál, M., Keményné Horváth, Z., Domán, C., Illés, I., Kiss, A., Péter, K., Kemény, G. (2018). Precision agriculture in Hungary: assessment of perceptions and accounting records of FADN arable farms. Studies in Agricultural Economics, 120(1), 47-54.

Tamás, J. (2001). Precíziós mezőgazdaság. Budapest: Mezőgazdasági Szaktudás Kiadó. 
termeszetvedelem.hu. (2020). http://www.termeszetvedelem.hu/index.php? pg=menu_2090 (30.07.2020).

Udvardy, P. (2010). Agrártermelés és agrárpolitika Magyaror-szágon. Agrár- és vidékfejlesztési stratégiák regionális alkalmazása, 4. https://regi.tankonyvtar.hu/hu/tartalom/tamop425/0027_ AVF4/ch01.html (30.07.2020).

UNCCD. (2006). Second National Report of the Republic of Hungary on the implementation of the United Nation Convention to Combat Desertification. Budapest: Ministry of Environment and Water of the Republic of Hungary.

Varga, E., Alicki, K., Vőneki, É. (eds.). (2013). A magyar mezőgazdaság föbb ágazatainak helyzete, piaci kilátásai rövid és középtávon. Budapest: Research Institute of Agricultural Economics.

Vöneki, É., Mándi-Nagy, D. (2014). A tejágazat kilátásai a kvótarendszer megszüntetése után. Budapest: Research Institute of Agricultural Economics. 